\title{
ABAD'IN ACHMEA KARARI VE YATIRIMCI-DEVLET UYUŞMAZLIK ÇÖZÜMÜ AÇISINDAN YANSIMALARI
}

\begin{abstract}
Mustafa Alper ENER ${ }^{*}$
$\ddot{O} Z$

Avrupa Birliği Adalet Divanı'nın vermiş olduğu Achmea kararı sadece Avrupa Birliği için değil etkileri dolayısıyla anlaşmaya dayanan yatırımcı-devlet uyuşmazlıklarının çözümünde bir milat olarak kabul edilebilir. Bu kararın ne kadar doğru ne kadar yanlış olduğu yıllar geçtikçe ortaya çıkacak olsa da, çalışmamızda söz konusu karar özellikle Hukuk Sözcüsü Wathelet'in görüşü ile birlikte değerlendirilmektedir. Achmea kararının yansımalarını incelemeden önce Avrupa Birliği Adalet Divanı'nın yapısı, ön karar prosedürü, Achmea davasının arka planı, Achmea davasında görevlendirilen Hukuk Sözcüsü'nün görüşü ve son olarak Avrupa Birliği Adalet Divanı'nın verdiği yatırımcı-devlet uyuşmazlık çözümünü ilgilendiren en önemli kararlardan biri olan Achmea kararı incelenerek sonuç kısmında bu kararın doğurabileceği muhtemel sonuçlar ele alınmaktadır.
\end{abstract}

Anahtar Kelimeler: Achmea, Ön Karar Prosedürü, Yatırımcı-Devlet Uyuşmazlık Çözümü, Gün Batımı Hükümleri, Avrupa Birliği Adalet Divanı.

\section{THE CJEU'S ACHMEA DECISION AND ITS ECHOES ON INVESTOR- STATE DISPUTE SETTLEMENT}

\section{ABSTRACT}

The Achmea decision of the Court of Justice of the European Union might be seen as a landmark not just for European Union but because of its impacts to the entire treaty-based investor-state dispute settlement mechanism. Even though whether this decision is accurate or not will become evident in the years to come, in this paper the Achmea decision is evaluated together with the arguments used in the opinion of Advocate General Wathelet. Before discussing echoes of Achmea decision on investorstate dispute settlement, the structure of Court of Justice of the European Union and its preliminary ruling procedure, background of Achmea case, opinion of Advocate General and Achmea ruling itself examined.

Keywords: Achmea, Preliminary Ruling Procedure, ISDS, Sunset Clause, Court of Justice of the European Union.

* Arş. Gör. Dr., Ankara Hacı Bayram Veli Üniversitesi Hukuk Fakültesi Milletlerarası Özel Hukuk ABD / ANKARA, e-posta: mustafa.ener@hbv.edu.tr

ORCID: 0000-0002-7575-6879

DOI : $10.34246 /$ ahbvuhfd.1066635

Yayın Kuruluna Ulaştığı Tarih $\quad:$ : 18/11/2021

Yayınlanmasının Uygun Görüldüğü Tarih: 12/01/2022 
Abad'ın Achmea Kararı ve Yatırımcı-Devlet Uyuşmazlık Çözümü Açisindan...

\section{GİRIŞ}

Almanya-Pakistan arasında 29 Kasım 1959 tarihinde akdedilen ilk yatırımların teşviki ve korunması anlaşmasıyla birlikte yatırımcılar ile devlet arasında doğan uyuşmazlıkların ev sahibi devlet mahkemelerinde görülmesi yerine tarafsızlık ve bağımsızlık yönü ağır basan milletlerarası tahkim yoluyla çözülmesi yoluna gidilmesi tercih edilmeye başlanmıştır. Bu süreç içerisinde bilinen yatırımcı-devlet uyuşmazlık çözümü davalarının sayısı 2020 yılının sonunda 1104'e yükselmiştir. ${ }^{1}$

Her sistem gibi yatırımcı-devlet uyuşmazlık çözümü mekanizmasının da geliştirilmesi, günün ihtiyaçlarına ayak uydurması ve sahip olduğu sorunlu alanların düzeltilmesi gerekmektedir. Birleşmiş Milletler Uluslararası Ticaret Hukuku Komisyonu'nun (United Nations Commission on International Trade Law - "UNCITRAL") özellikle Tahkim Kuralları (UNCITRAL Arbitration Rules), Anlaşmaya Dayanan Yatırımcı-Devlet Tahkiminde Şeffaflık Kuralları (UNCITRAL Rules on Transparency in Treaty-based InvestorState Arbitration $)^{2}$ gibi metinlerini oluştururken ve güncellerken yaptı̆̆ 1 kapsamlı çalışmalar bulunmaktadır. 2017 yılındaki 50. oturumunda bazı kurumlar tarafindan kaleme alınan yatırımc1-devlet tahkimindeki sorunlar ve reform tekliflerini, bazı uluslararası kuruluşlar ve devletlerin bu konudaki yorumlarını gözeterek, yatırımcı-devlet uyuşmazlık çözümü mekanizmasında yapılabilecek olası reformlar için Çalışma Grubu III'ün çalışmalara başlaması kararı alınmıştır. ${ }^{3} 2016$ yılında başlatılan AB-içi yatırım tahkim davaları o yıl açılan yatırım uyuşmazlığı tahkim davalarının (62) yaklaşık dörtte birini; ${ }^{4}$ 2017 yılında başlatılanlar o yıl açılan yatırım uyuşmazlığı tahkim davalarının (65) yaklaşık beşte birini; ${ }^{5}$ Achmea kararının verildiği yıl olan 2018'de başlatılanlar o yıl açılan yatırım uyuşmazlığı tahkim davalarının (71) yaklaşık

UNCTAD, Investor-State Dispute Settlement Cases: Facts and Figures 2020, IIA Issue Note, Issue 4, September 2021, s. 1.

2 UNCITRAL, Rules on Transparency in Treaty-based Investor-State Arbitration, United Nations New York, 2014.

3 United Nations, Report of the United Nations Commission on International Trade Law, Fiftieth Session (3-21 July 2017), General Assembly Official Records Seventy-second Session, Supplement No. 17, A/72/17, New York, 2017, s. 2-3.

4 UNCTAD, Investor-State Dispute Settlement: Review of Developments in 2016, IIA Issues Note, Issue 1, May 2017, s. 1-2.

5 UNCTAD, Investor-State Dispute Settlement: Review of Developments in 2017, IIA Issues Note, Issue 2, June 2018, s. 1-2. 
onda birini (6);6 AB Üye Devletlerinin $\mathrm{AB}$-içi ikili yatırım anlaşmalarının sona erdirilmesi takvimini ${ }^{7}$ yayımladıkları yıl olan 2019'da başlatılanlar o yıl açılan yatırım uyuşmazlığı tahkim davalarının (55) yaklaşık yüzde on beșini $(7)^{8}$ olușturmaktadır. AB Üye Devletleri Arasındaki İkili Yatırım Anlaşmalarının Feshi Anlaşması'nın (Fesih Anlaşması) ${ }^{9}$ yayımlandığ 2020 yılına gelindiğinde ise açılan 68 anlaşmaya dayanan yatırımc1-devlet tahkimi davasından 9'u AB-içi uyuşmazlıklardır ve bunların 5'i AB-içi İkili Yatırım Anlaşmalarına, 4'ü ise Enerji Şartı Anlaşmasına dayanmaktadır. ${ }^{10}$

Çalışmamızda öncelikle Avrupa Birliği Adalet Divanı'nın yapısı, ön karar prosedürü, Achmea davasının arka planı ve Achmea davasında görevlendirilen Hukuk Sözcüsü'nün görüşü incelenecektir. Çalışmanın sonraki kısmında Avrupa Birliği Adalet Divanı'nın verdiği yatırımcı-devlet uyuşmazlık çözümünü ilgilendiren en önemli kararlarından biri olan Achmea kararı incelenecek, sonuç kısmında ise bu kararın tahkim hukuku boyutundaki yansımalarının nasıl olacağı ele alınacaktır.

\section{Avrupa Birliği Adalet Divanı}

Avrupa Birliği Adalet Divanı (ABAD - Court of Justice of the European Union - CJEU), Adalet Divan1 (Court of Justice) ve Genel Mahkeme'den (General Court $)^{11}$ teşekkül etmektedir. ABAD'ın öncüsü olan Adalet Divanı,

6 UNCTAD, Investor-State Dispute Settlement: Review of Developments in 2018, IIA Issues Note, Issue 2, May 2019, s. 1-3.

7 Declaration of the Representatives of the Governments of the Member States on the Legal Consequences of the Judgement of the Court of Justice in Achmea and on Investment Protection in the European Union, 15 January 2019, <https://ec.europa.eu/info/sites/default/files/ business_economy_euro/banking_and_finance/documents/190117-bilateral-investmenttreaties_en.pdf> Erişim Tarihi 15.11.202 1 .

8 UNCTAD, Investor-State Dispute Settlement Cases Pass the 1,000 Mark: Cases and Outcomes in 2019, IIA Issues Note, Issue 2, July 2020, s. 1-3.

9 Agreement for the Termination of Bilateral Investment Treaties Between the Member States of the European Union, SN/4656/2019/INIT, OJ L 169, 29.5.2020, s. 1-41. Anlaşmanın önsözünde bu anlaşmanın AB-içi IYYA'lara dayanarak açılan bütün yatırımcı-devlet tahkim yargılamalarını kapsadığı belirtilmektedir. Kapsam içerisinde ICSID Konvansiyonu ve ICSID, PCA, SCC, ICC, UNCITRAL tahkim kurallarına göre görülen tahkim yargılamaları ve ad hoc tahkim de sayılmıştır. Avusturya, Finlandiya, İrlanda ve İsveç şimdiye kadar bu anlaşmaya imza atmamıştır.

10 UNCTAD, Investor-State Dispute Settlement Cases: Facts and Figures 2020, s. 2.

11 ABAD içerisinde 2004 yılında kurulan Avrupa Birliği Kamu Personeli Mahkemesi, AB’nin yargı sisteminde yapılan reform kapsamında görevinin ve görülmekte olan davaların Genel Mahkeme'ye devredilmesiyle 1 Eylül 2016 tarihi itibariyle kapatılmıştır. Regulation (EU, 
Abad'ın Achmea Kararı ve Yatırımcı-Devlet Uyuşmazlık Çözümü Açisindan...

Avrupa Kömür ve Çelik Topluluğunu Kuran Antlaşma'yla bu antlaşmanın ve uygulama yönetmeliklerinin yorum ve uygulanmasında hukuka uyulmasını sağlamak için oluşturulmuştur. ${ }^{12} \mathrm{ABAD}, \mathrm{AB}$ hukukunun bütün $\mathrm{AB}$ üyesi ülkelerdeaynı șekildeyorumlanmasını veuygulanmasını sağlamaklagörevlidir. Adalet Divanı, her AB ülkesinden bir hâkim ve 11 hukuk sözcüsünden ${ }^{13}$ meydana gelmektedir. ${ }^{14}$ Genel Mahkeme ise 1 Eylül 2019 tarihinden itibaren her AB Üye Devletinden gelen iki hâkimden oluşmaktadır. ${ }^{15}$

ABAD("Mahkeme")önüneen sıkgelen davaları; önkararmekanizmasıyla $\mathrm{AB}$ hukukunun yorumlanması ve milli hukukların $\mathrm{AB}$ hukukuna uyumunun belirlenmesi, ihlale karşı başvuru mekanizması ile milli hükümetlerin $\mathrm{AB}$ hukukunu uygulamasının sağlanması, iptal davası ile AB Antlaşmalarını ve temel hakları ihlal ettiği ileri sürülen düzenlemelerin denetlenmesi, menfi işlemin tespiti (ihmal) davası ile AB Parlamentosu, Konsey veya Komisyonun belirli kararları almaması durumunda harekete geçmeye zorlanması, tazminat davası ile AB'nin işlemleri veya ihmali nedeniyle hakları zarar gören kişilerin AB kurumlarına müeyyide uygulanması için açtığı davalar olarak sayabiliriz. ${ }^{16}$

Euratom) 2016/1192 of the European Parliament and of the Council of 6 July 2016 on the transfer to the General Court of jurisdiction at first instance in disputes between the European Union and its servants, OJ L 200, 26.7.2016, s. 137-139.

12 AKÇTKA m. 31-45. Avrupa Birliği Adalet Divanı'nın tarihçesi için bkz. Sanem Baykal, İlke Göçmen, Avrupa Birliği Kurumsal Hukuku, 1. Baskı, Seçkin Yayıncılık, Ankara, 2016, s. $211 \mathrm{vd}$.

13 2013/336/EU: Council Decision of 25 June 2013 Increasing the Number of Advocates-General of the Court of Justice of the European Union, OJ L 179, 29.6.2013, s. 92.

14 Avrupa Birliği Antlaşması (“ABA”) m. 19; Avrupa Birliği’nin İşleyişi Hakkında Antlaşma (“ABİHA") m. 252.

15 Consolidated versions of the Treaty on European Union and the Treaty on the Functioning of the European Union Consolidated version of the Treaty on European Union Consolidated version of the Treaty on the Functioning of the European Union Protocols Annexes to the Treaty on the Functioning of the European Union Declarations annexed to the Final Act of the Intergovernmental Conference which adopted the Treaty of Lisbon, signed on 13 December 2007 Tables of equivalences, OJ C 202, 7.6.2016, s. 210-226. ABAD Statüsü Hakkında Protokol (No 3) (“ABAD Statüsü”) m. 48.

16 ABAD'da görülen dava türleri ve ABAD’da Adalet Divanı ve genel mahkemenin yargı yetkisinin bölüşümü için bkz. Baykal/Göçmen, s. 219-222; 379 vd.; Pelin Aktoprak, "Lizbon Antlaşması Sonrası Avrupa Birliği Adalet Divanı Bakımından Temel Hakların İncelenmesi”, 2017, 19(Özel Say1), DEÜ Hukuk Fakültesi Dergisi, Prof. Dr. Şeref Ertaş'a Armağan, s. 3044-3047; Servet Alyanak, “Avrupa Birliği Adalet Divanı'nın Teşkilatlanması”, 2014, 72(3), Ankara Barosu Dergisi, s. 257-259; EU Institution, Court of Justice of the European Union (CJEU), <https://europa.eu/european-union/about-eu/institutions-bodies/court-justice_en> Erişim Tarihi 15.11.2021. 
Davalar, davanın önemine ve kapsamına göre üç, beş (Daireler) veya on beş hâkim (Büyük Daire) ${ }^{17}$ tarafından görülmektedir. ${ }^{18}$ Avrupa Birliği'nin İşleyiși Hakkında Antlaşma (ABİHA - Treaty on the Functioning of the European Union - TFEU) m. 228/2, 245/2, 247 veya 286/6 uyarınca açılan davalarda 27 hâkim (tam mahkeme) tarafından dava görülmektedir. ${ }^{19}$ Öncelikle raportör hâkim tarafından dava özetlenmekte ve sonra mahkemenin genel toplantısında davanın kaç hâkim ile görüleceğine, duruşma yapılıp yapılmayacağına ve hukuk sözcüsünün görüşünün gerekli olup olmadığına karar verilmektedir.

Adalet Divanı'nda prosedür yazılı ve sözlü olmak üzere iki kısımdan oluşmaktadır. Yazılı prosedürde başvurular, taraflara ve kararı uyuşmazlığa konu olan AB kurumuna bildirim yapılması, davaya ilişkin beyanlar, savunmalar, görüşler, cevaplar ve varsa iddiaları destekleyici belgelerin Mahkeme'ye iletilmesi ile gerçekleşmektedir. Sözlü prosedür ise Mahkeme'nin vekiller, danışmanlar ve avukatlarla birlikte hukuk sözcüsünün de görüşlerini almasını ve varsa tanık ve bilirkişileri dinlemesini içermektedir. Mahkeme, hukuk sözcüsünü dinledikten sonra, davada hukuka ilişkin yeni bir mesele olmadığına kanaat getirirse, hukuk sözcüsünün görüşü olmadan dava hakkında kararını verir. ${ }^{20}$

\section{II. Ön Karar Prosedürü (Preliminary Ruling Procedure)}

Avrupa Birliği Anlaşması ("ABA") m. 19'da, ABAD'ın Avrupa Birliği'nin üzerine kurulmuş olduğu ABA ve ABİHA'nın (“Antlaşmalar") ${ }^{21}$ yorumlanmasında ve uygulanmasında hukuka uyulmasını sağlamak için kurulduğu ifade edilmektedir. ABA m. 19/3-b'ye göre ABAD'ın, Üye Devletlerin mahkemeleri veya yargılama yetkisi olan makamlarının (court or

17 Çalışmamızda yer alan Achmea ve Komstroy davaları on beş hâkim tarafindan görülen davalardandır.

18 ABAD Statüsü m. 16.

19 ABAD Statüsü m. 16.

20 ABAD Statüsü m. 20.

21 Consolidated versions of the Treaty on European Union and the Treaty on the Functioning of the European Union Consolidated version of the Treaty on European Union Consolidated version of the Treaty on the Functioning of the European Union Protocols Annexes to the Treaty on the Functioning of the European Union Declarations annexed to the Final Act of the Intergovernmental Conference which adopted the Treaty of Lisbon, signed on 13 December 2007 Tables of equivalences, OJ C 202, 7.6.2016, s. 1-388. 
Abad'ın Achmea Kararı ve Yatırımcı-Devlet Uyuşmazlık Çözümü Açisindan...

tribunals) ${ }^{22}$ talebi üzerine $\mathrm{AB}$ hukukunun yorumlanması veya $\mathrm{AB}$ kurumları tarafindan gerçekleştirilen tasarrufların geçerliliği (hukuka uygunluğu) hakkında ön karar vereceği belirtilmektedir. Ön karar prosedürü ile $A B$ hukukunun bütün $\mathrm{AB}$ üyesi devletlerde yeknesak şekilde uygulanması ve doğru yorumunun belirlenmesi amaçlanmaktadır. Bu amacın gerçekleştirilmesi için Adalet Divanı'na AB hukukunu yorumlama tekeli verilmiştir. ${ }^{23}$

Avrupa Birliği'nin İşleyişi Hakkında Antlaşma m. 267'de ABAD'ın hangi konularda ön karar vereceği düzenlenmiştir. Buna göre, Antlaşmaların yorumlanması ile AB kurumları, organları, ofisleri ve ajanslarının tasarruflarının geçerliliği ve yorumlanması hakkında ön karar vermektedir. ${ }^{24}$ AB Üye Devletlerinin mahkemeleri veya yargılama yetkisi olan makamları önündeki bir davada bu konularda bir ön sorun ortaya çıktı̆̆ında, mahkeme veya makam karar vermesi için o sorun hakkında ön karar verilmesini zorunlu görmekteyse ABAD'dan bu sorun hakkında karar vermesini talep edebilmektedir. ${ }^{25} \mathrm{Bu}$ anlamda ön karar prosedürüne başvuru sadece $\mathrm{AB}$ Üye Devletlerinin mahkemeleri veya yargılama yetkisi olan makamları tarafindan yapılabilmektedir. Ancak, bu konularda sorunun milli mahkemelerde veya makamlarda görülen ve iç hukuka göre verilen karara karşı kanun yolunun kapalı olduğu bir davada bu konularda bir sorunun ortaya çıkması durumunda, bu mahkeme veya makamın sorunu ABAD'a götürmesi zorunludur. ${ }^{26}$

Ön karar prosedürünün işleyişi ABAD Statüsü m. 23'te düzenlenmektedir. ABİHA m. 267 uyarınca görülen davalarda, yargılamayı bekleten ve ABAD'a ön karar için başvuran mahkeme veya makamın kararı, o mahkeme veya makam tarafından ABAD'a bildirilir. Ardından karar ABAD'ın Başkatipliği tarafindan taraflara, Üye Devletlere ve Komisyon'a ve geçerliliği veya yorumu uyuşmazlık konusu olan tasarrufu kabul eden AB kurum, organ, ofis

22 Mahkeme veya yargılama yetkisi makam kavramının hangi ölçütlere göre belirlendiği konusunda bkz. Baykal/Göçmen, s. 504-506.

23 Carl Otto Lenz, "The Role and Mechanism of the Preliminary Ruling Procedure", 1994, 18(2), Fordham International Law Journal, s. 389.

24 Ön karar prosedürüne $\mathrm{AB}$ hukukunun yorumlanması veya $\mathrm{AB}$ kurumları tarafından gerçekleştirilen tasarrufların geçerliliği yönünden hangi konularla ilgili başvurulabileceği hakkında bkz. Baykal/Göçmen, s. 499-503. Füsun Arsava, Roma Antlaşmasında Ön Karar Prosedürü ve Bu Prosedür Çerçevesinde Doğan Sorunlar, Ankara Üniversitesi Avrupa Topluluğu Araştırma ve Uygulama Merkezi Araştırma Dizisi No: 31, Ankara, 2009, s. 21 vd.

25 ABİHA m. 267/2.

26 ABİHA m. 267/3. 
veya ajansına bildirilir. ${ }^{27}$

Bildirimden itibaren iki ay içerisinde, taraflar, Üye Devletler, Komisyon ve geçerliliği veya yorumu uyuşmazlık konusu olan tasarrufu kabul eden ilgili kurum, organ, ofis veya ajans, davaya ilişkin beyanlarını veya yazılı görüşlerini ABAD'a iletme hakkına sahiptir. ${ }^{28}$ Eğer söz konusu uyuşmazlık Avrupa Ekonomik Alanı Anlaşması'nın (AEAA - Agreement on the European Economic Area - AEEA) uygulanmasına ilişkin alanlardan birine girmekteyse, mahkeme veya makamın kararı ABAD Başkatipliği tarafından AEAA taraf devletlerine ve bu anlaşmada belirtilen EFTA Gözetim Kurumu'na iki ay içerisinde ABAD'a beyanlarını veya yazılı görüşlerini iletmeleri için bildirilir. ${ }^{29}$ Konsey ile AB üyesi olmayan bir veya birden fazla devlet arasinda akdedilen anlaşmalarda yer alan bir konuya ilişkin anlaşmada o devletlerin, o anlaşmanın kapsamına giren bir sorun hakkında AB Üye Devletlerinden birinin mahkeme veya makamı tarafından ABAD'a ön karar için gönderilen bir davada ABAD'a beyanlarını veya yazılı görüşlerini iletmelerine imkân tanınmaktaysa, sorunu içeren milli mahkeme veya makamın kararı ilgili üye olmayan devletlere de bildirilir. ${ }^{30}$

Usul Kuralları uyarınca Adalet Divanı seri veya hızlandırılmış usul; özgürlük, güvenlik ve adalet alanlarına ilişkin ön karar için başvurulması durumunda ise acil usul uygulayabilir. ${ }^{31} \mathrm{Bu}$ usullerde davaya ilişkin beyanların ve yazılı görüşlerin m. 23 'te belirtilen sürelerden daha kısa süre içerisinde sunulması veya m. 20/4'e istisna olarak hukuk sözcüsünün görüşü olmadan karar verilmesi öngörülebilir. ${ }^{32}$ Ayrıca acil usulde m. 23 'te belirtilen tarafların ve diğer ilgili kişilerin davaya ilişkin beyanlarını ve yazılı görüşlerini iletme haklarına sınırlama getirilebilir, hatta çok acil durumlarda yazılı aşamanın geçilmesine imkân sağlanabilir. ${ }^{33}$

\section{Hukuk Sözcülerinin Görüssleri}

Hukuk sözcüsü, Adalet Divanı'nın bir üyesi olmakla birlikte, karar verme mekanizmalarında yer almamaktadır. Hukuk sözcüsünün görüşünün gerekli

\footnotetext{
ABAD Statüsü m. 23/1.

28 ABAD Statüsü m. 23/2.

29 ABAD Statüsü m. 23/3.

30 ABAD Statüsü m. 23/4.

1 ABAD Statüsü m. 23a/1.

ABAD Statüsü m. 23a/2.

33 ABAD Statüsü m. 23a/3.
} 
Abad'ın Achmea Kararı ve Yatırımcı-Devlet Uyuşmazlık Çözümü Açisindan...

olduğuna karar verilmesi durumunda, duruşmanın yapılmasından belirli bir süre sonra hukuk sözcüsü görüşünü Mahkeme'ye sunmaktadır. ${ }^{34} \mathrm{Bu}$ görüş tamamen bağımsız bir şekilde uyuşmazlığın nasıl çözülmesi gerektiğine dair hukuk sözcüsünün kanaatlerini ve dayanaklarını içermektedir. ${ }^{35}$ Mahkeme, hukuk sözcüsünün görüşüne uyup uymamakta serbesttir.

\section{Achmea Davasının Arka Planı}

Almanya Federal Adalet Mahkemesi'nin Achmea davasinda 3 Mart 2016 tarihinde verdiği kararıyla, Avrupa Birliği'nin İşleyişi Hakkında Antlaşma'nın 267. maddesi kapsamında yapılan ön karar başvurusu 23 Mayıs 2016 tarihinde ABAD'a ulaşmıştır. Söz konusu davada Hollanda merkezli bir sigorta grubunun girişimi olan Achmea BV (eski adıyla Eureko BV), 2004 yılında Slovakya Cumhuriyeti'nin sağlık reformu kapsamında özel sağlık sigortası hizmetini serbest piyasaya açmasının ardından Slovakya'da 72 Milyon Euro sermaye ile Union Healthcare adıyla bağlı bir şirket kurmuştur. 2006 yılında Slovakya'da hükümetin değişmesiyle birlikte özel sağlık sigortası pazarının serbestleştirilmesi kısmen geri alınmıştır. 25 Ekim 2007 tarihli bir kanunla, özel sağlık sigortası faaliyetlerinden elde edilen kârların dağıtılması yasaklanmıştır. Slovakya Cumhuriyeti Anayasa Mahkemesi 26 Ocak 2011 tarihli bir kararında bu yasağın Slovakya Anayasası'na aykırı olduğuna karar vermiştir. Ardından Slovakya Cumhuriyeti'nde 1 Ağustos 2011 tarihinde yürürlüğe giren bir kanunla söz konusu kârların dağıtılmasına tekrar izin verilmiştir. ${ }^{36}$

Achmea, Slovakya Cumhuriyeti'nin koyduğu yasal sinırlamalar dolayısıyla 65 Milyon Euro zarara uğradığını ve bunun Hollanda Krallığ ile Çek ve Slovak Federatif Cumhuriyeti arasında Yatırımların Teşviki ve Karşılıklı Korunması Anlaşması'nın (IYYA) 3/1, 3/2, 4 ve 5. maddelerini ihlal ettiğini iddia etmiş ve söz konusu Anlaşma'nın 8. maddesine dayanarak 1 Ekim 2008'de Slovakya Cumhuriyeti aleyhine tahkime başvurmuştur. Tahkim mahkemesi ve taraflar, kayıt merciinin Daimî Tahkim Mahkemesi olması ve tahkim dilinin İngilizce olması üzerine mutabık kalmışlardır. Tahkim

\footnotetext{
ABİHA m. 252/2.

ABAD Statüsü m. 49/2.

36 Judgment of the Court (Grand Chamber), Case C-284/16, Slowakische Republik (Slovak Republic) v. Achmea BV, ECLI:EU:C:2018:158, 6 March 2018 (ABAD Achmea Karar1), para. 7-8. Kararın tam metni için bkz. $<$ https://curia.europa.eu/juris/document/document.jsf ?text $=\&$ docid $=199968 \&$ pageIndex $=0 \&$ doclang $=\mathrm{EN} \&$ mode $=1$ st $\&$ dir $=\&$ occ $=$ first $\&$ part $=1 \&$ cid $=41922798>$ Erişim Tarihi 15.11.2021.
} 
mahkemesi 1 No'lu Ara Kararı ile tahkim yerini Frankfurt - Almanya olarak belirlemiştir. ${ }^{37}$

Slovakya Cumhuriyeti,Avrupa Birliği'nin İşleyişi HakkındaAntlaşma'nın (ABİHA) İYA ile aynı konuları düzenlediğini, bu nedenle uygulanamayacağını veya İYA'nın 1969 Antlaşmalar Hukuku Hakkında Viyana Konvansiyonu m. 30 ve m. 59 uyarınca sona erdirilmesi gerektiğini ileri sürerek tahkim mahkemesinin yetkisine itiraz etmiştir. Ayrıca, uyuşmazlığın tahkime götürülmesine ilişkin IYYA'nın 8/2 maddesinin ABİHA'ya aykırı olduğunu ve bu nedenle uygulanamayacağını iddia etmiştir. Tahkim mahkemesi, 26 Ekim 2010 tarihli Yetki, Tahkime Elverişlilik ve Erteleme hakkında ara kararıyla itirazı reddetmiş ve yetkili olduğuna karar vermiştir. ${ }^{38} \mathrm{Bu}$ ara kararın iptali için Slovak Cumhuriyeti'nin Alman mahkemelerinde yaptığ 1 başvurular ilk derece ve temyiz mahkemelerinde reddedilmiştir.

Tahkim mahkemesi, 7 Aralık 2012 tarihli Nihai Karar1 $1^{39}$ ile kâr dağıtımının engellenmesi ile sermayenin ülkeden çıkarılmasının önüne geçilmesinin IYA m. 3'te yer alan adil ve hakkaniyete uygun muamele standard, $\mathrm{m}$. 4 'te yer alan sermayenin ülkeden serbestçe çıkarılması hükümlerini ihlal ettiği gerekçesiyle Slovakya Cumhuriyeti'nin Achmea'ya tazminat olarak 22.1 Milyon Euro ana para ile birlikte faizini ve Achmea'nın tahkim, hukuki temsil ve danışmanlık masraflarını ödemesine hükmetmiştir. ${ }^{40}$ Tahkim mahkemesi Achmea'nın kamulaştırma iddiasını ise reddetmiştir. ${ }^{41}$

Slovakya Cumhuriyeti hakem kararının iptali için Frankfurt Yüksek Bölge Mahkemesi'nde kararın kamu düzenine aykırı olduğu, karara konu olan tahkim anlaşmasının geçersiz ve kamu düzenine aykırı olduğu iddiası

\footnotetext{
37 ABAD Achmea Kararı, para. 9-10. Achmea B.V. (formerly known as Eureko B.V.) v. The Slovak Republic, Final Award, PCA Case No. 2008-13, 7 December 2012 (7 Aralık 2012 tarihli Nihai Karar), para. 12. Opinion of Advocate General Wathelet, Case C-284/16, Slowakische Republik v Achmea BV, ECLI:EU:C:2017:699, 19 September 2017 (Wathelet), para. 20-21.

38 Eureko B.V. v. The Slovak Republic, Award on Jurisdiction, Arbitrability and Suspension, PCA Case No. 2008-13, 26 October 2010. 26 Ekim 2010 tarihli Yetki, Tahkime Elverişlilik ve Erteleme Hakkında Ara Karar. Karara ulaşmak için bkz. $<$ https://pcacases.com/web/sendAttach/775> Erişim Tarihi 15.11.2021.

39 Achmea B.V. (formerly known as Eureko B.V.) v. The Slovak Republic, Final Award, PCA Case No. 2008-13, 7 December 2012. Karara ulaşmak için bkz. <https://pcacases.com/web/ sendAttach/785> Erişim Tarihi 15.11.2021.

$40 \quad 7$ Aralık 2012 tarihli Nihai Karar, para. 352.

417 Aralık 2012 tarihli Nihai Karar, para. 292-293.
} 
Abad'ın Achmea Kararı ve Yatırımcı-Devlet Uyuşmazlık Çözümü Açisindan...

ile dava açmıştır. Mahkeme bu davay1 18 Aralık 2014 tarihinde reddetmiştir. ${ }^{42}$ Slovakya Cumhuriyeti bu ret kararını hukukun yanlış uygulanması nedeniyle Almanya Federal Adalet Mahkemesi'nde temyiz etmiştir. ${ }^{43}$

Almanya Federal Adalet Mahkemesi Slovakya Cumhuriyeti'nce ileri sürülen IYYA'da yer alan uyuşmazlıkların tahkime götürülebilmesine imkân tanıyan maddenin ABİHA'nın 18, 267 ve 344. maddeleriyle uyumlu olmadığ 1 görüşünü paylaşmasa da, Mahkeme'nin bu konularda daha önce karar vermediğini, var olan içtihat hukukundan bunun cevabının yeterli kesinlikte çıkarılamayacağını ve Avrupa Komisyonu'nun tahkim ve iptal davası sürecinde Slovakya Cumhuriyeti'ni destekleyecek şekilde müdahil olmasını dikkate alarak davanın bekletilmesine ve ön karar için bazı soruların ABAD'a gönderilmesine karar vermiştir. ${ }^{44} 23$ Mayıs 2016 tarihinde ön karar talebi Mahkeme'ye ulaşmıştır.

\section{V.Hukuk Sözcüsü Wathelet'in Görüşü}

Achmea davasında Hukuk Sözcüsü Melchior Wathelet'in ("Hukuk Sözcüsü’)19Eylül2017 tarihindeMahkeme'ye ulaşan görüşü45 dava sonucunda verilen kararın arka planındaki hukuki ve siyasi yönün anlaşılmasında büyük önem arz etmektedir. Wathelet, ön karar için gönderilen sorular hakkındaki görüşlerini belirtmeden önce bazı gözlemlerini aktarmaktadır.

Bu gözlemlerden ilki, davaya müdahil olan Üye Devletlerden İYA'da yer alan uyuşmazlık çözümüne dair hükmün ABİHA'yla çelişmediğini ileri süren ve ABİHA'ya aykırı olduğunu ileri süren iki grubun sahip olduğu özelliklerdir. Almanya, Fransa, Hollanda, Avusturya ve Finlandiya'dan oluşan ilk grubun genellikle yatırımcıların vatandaşı olduğu devletler olduğu ve bu nedenle ya hiç ya da çok nadir şekilde yatırımcılar tarafından başlatılan tahkim yargılamalarıyla karşılaştıklarını belirtmektedir. İkinci grubun ise Çekya, Estonya, Yunanistan, İspanya, İtalya, Güney Kıbrıs Rum Yönetimi,

42 Judgment of the Higher Regional Court of Frankfurt, Oberlandesgericht Frankfurt am Main Beschl. v. 18.12.2014, Az.: 26 Sch 3/13, <https://www.italaw.com/sites/default/files/casedocuments/italaw7079.pdf $>$ Erişim Tarihi 15.11.2021.

43 Wathelet, para. 25.

44 Wathelet, para. 29-30.

45 Opinion of Advocate General Wathelet, Case C-284/16, Slowakische Republik v Achmea BV, ECLI:EU:C:2017:699, 19 September 2017. Tam metne ulaşmak için bkz. <https:// eur-lex.europa.eu/legal-content/en/TXT/?uri=CELEX:62016CC0284> Erişim Tarihi 15.11.2021. 
Letonya, Macaristan, Polonya, Romanya ve Slovakya'dan oluştuğunu ve AB-içi yatırıma ilişkin birden fazla tahkim yargılamasında davalı olduğunu ifade etmektedir. ${ }^{46}$ Wathelet, Slovakya'nın görüşünü destekleyen devletlerin durumunun ekonomik gerçekliklere bakıldığında şaşırtıcı olmadığını söylemektedir. ${ }^{47}$

Hukuk Sözcüsü'nün ikinci gözlemi, İtalya haricinde, Slovakya'nın yanında $A B$-içi İYA'ların AB hukukuna ve ABİHA'ya uyumlu olmadığı görüşünü destekleyen devletlerin, AB-içi İYA'larını sona erdirmediklerini ve yatırımcılarının bu IYYA'lardan yararlanmaya devam etmesini sağladıklarını tespit etmesidir. ${ }^{48}$ Duruşma sırasında Slovakya'ya taraf olduğu ve AB hukukuyla uyumlu olmadığını iddia ettiği AB-içi İYA'ları neden sona erdirmediği sorulmuştur. Slovakya Cumhuriyeti bu soruya amacının IYYA'ları sona erdirdiği devletlerde kendi vatandaşı olan yatırımcıların diğer Üye Devletlerin yatırımcılarına kıyasla ayrımcılığa maruz kalmamasını amaçladığ cevabını vermiştir. ${ }^{49}$

Wathelet'in diğer bir gözlemi ise Avrupa Komisyonu'nun ve $A B$ kurumlarının yıllar boyunca IYYA'ları Orta ve Doğu Avrupalı aday ülkelerin AB ile katılım müzakerelerinde katılıma hazırlık için imzalamaları gerekli görülen unsurlar arasında saymasıdır. Hatta $\mathrm{AB}$ ile zamanının aday ülkelerinden Macaristan, Polonya, Romanya, Slovakya, Hirvatistan gibi ülkelerin ortaklık anlaşmalarında Üye Devletlerle aday ülkeler arasında IYY'ların imzalanmasına dair hükümler yer almaktadır. Bu durum Hukuk Sözcüsü tarafindan çelişkili olarak görülmüş olmalıdır ki şu soruyu sormuştur: Eğer, bu IYYA'lar sadece katılım sürecinde geçerli ise ve Üye Devletler bunun AB Antlaşmaları ve ABİHA ile uyumlu olmadığının farkında ise neden katılım anlaşmaları bunların sona ermesine ilişkin hüküm içermemektedir ve neden bu anlaşmalar bazı Üye Devletler için 13 yıldır, bazılarında ise 30 yıldan fazla süredir devam etmektedir? ${ }^{50}$

\footnotetext{
46 Görüşün hazırlandığ1 tarihte Çekya 26, Estonya, GKRY ve Yunanistan 3'er, İspanya 33, İtalya 9, Letonya 2, Macaristan ve Polonya 11'er, Romanya 4, Slovakya ise 9 AB-içi yatırım tahkimi davasında davalı durumundadır.

47 Wathelet, para. 36.

48 Wathelet, para. 37.

49 Wathelet, para. 38.

50 Wathelet, para. 40-41.
} 
Abad'ın Achmea Kararı ve Yatırımcı-Devlet Uyuşmazlık Çözümü Açisindan...

Diğer önemli bir nokta ise Hukuk Sözcüsü'nün ABAD'1n 2 Eylül 2021 tarihinde Moldova v. Komstroy LLC $^{51}$ hakkında verilen ön kararı öngörmüş gibi Enerji Şartı Anlaşması'ndan (EŞA - Energy Charter Treaty - ECT) bahsetmesidir. ${ }^{52}$ Üye Devletler ve AB tarafindan ayrı ayrı imzalanan bütün tarafların eşit olduğu, yatırımların korunmasına ve yatırımcı-devlet uyuşmazlık çözümüne dair maddi hukuk hükümleri içeren milletlerarası bir anlaşma olan Enerji Şartı Anlaşması'nın AB Antlaşmaları ve ABİHA'ya uyumluluğuna ilişkin hiçbir Üye Devletin ABAD'dan görüş istememiş olmasını bu anlaşmaların $\mathrm{AB}$ hukukuyla uyumsuz olabileceğine ilişkin en ufak bir şüpheleri bile olmamasına bağlamıştır. ${ }^{53}$ Wathelet, Komisyon tarafından ileri sürülen AB-içi IYYA'ların AB hukukunun etkinliği açısından "sistemsel risk" oluşturduğu iddiasını ise aşırı abartılı bulmuştur. Tahkim mahkemelerinin genellikle Komisyon'un müdahil olmasına izin verdiğini ve müdahil olduğu on davanın hiçbirinde bu mahkemelerin AB'nin işlemlerinin geçerliliği veya Üye Devletlerin işlemlerinin $\mathrm{AB}$ hukukuna uyumunu incelemediği bilgisinde olduğunu ifade etmiştir. ${ }^{54}$ Hukuk Sözcüsü mevcut mesele ile alakalı görmese de, Komisyon ve bazı Üye Devletler AB hukukuyla uyumsuzluğu iddia edilen hakem kararı örneği olarak bir tek Micula davasın $1^{55}$ gösterebilmiştir. ${ }^{56}$

Son gözlem olarak, IYYA'ların diğer taraf devletin de AB'ye katılmasıyla doğrudan geçersiz olmadığı veya AB Antlaşmaları ve ABİHA ile uyumsuz hale gelmediğini, ilgili hükümlerin, bunların $\mathrm{AB}$ Antlaşmaları ve ABİHA ile uyumlu olduğu sürece geçerli olduğunu belirtmiştir. ${ }^{57}$

Wathelet gözlemlerinin ardından, başvuran mahkemenin sorduğu soruları üçüncüsünden cevaplamaya başlamıştır. Başvuran mahkeme üçüncü

\footnotetext{
51 Judgment of the Court (Grand Chamber), Case C-741/19, Republic of Moldova v. Komstroy LLC (successor in law to the company Energoalians), ECLI:EU:C:2021:655, 2 September 2021 (Komstroy kararı). Kararın tam metni için bkz. <https://curia.europa.eu/juris/ document $/$ document.jsf?text $=\&$ docid $=245528 \&$ pageIndex $=0 \&$ doclang $=$ en $\&$ mode $=1$ st $\&$ dir $=\&$ occ $=$ first\&part $=1 \& \mathrm{cid}=635097>$ Erişim Tarihi 15.11.2021.

52 Wathelet, para. 43.

53 Wathelet, para. 43.

54 Wathelet, para. 45. Bu görüşü paylaşan Gaillard, uygulamada tahkim mahkemelerinin önüne $\mathrm{AB}$ hukuku meselelerinin pek gelmediğini, söz konusu Achmea davasında da $\mathrm{AB}$ hukukunu ilgilendirmediğini ifade etmiştir. Emmanuel Gaillard, "The Myth of Harmony in International Arbitration", 2019, 34(3), 2018 Lalive Lecture, ICSID Review, s. 556.

55 Ioan Micula and Others v. Romania, ICSID Case No ARB/05/20.

56 Wathelet, para. 45.

57 Wathelet, para. 46-47.
} 
soru olarak ABİHA m. 18'in Hollanda-Çekoslovakya IYYA m. 8 ile oluşturulan yatırımcı-devlet uyuşmazlık çözümü mekanizmasını devre dışı bırakacak şekilde yorumlanıp yorumlanmayacağını sormuştur. ABİHA bu maddede ayrımcılık yasağını düzenlemektedir. Buna göre, tabiiyetten kaynaklanan nedenlerle meydana çıkabilecek her tür ayrımcılık yasaklanmaktadır. Wathelet'e göre, Slovakya ile ikili yatırım anlaşması olmayan bir AB Üye Devleti vatandaşı olan yatırımcılara $A B$ hukukunca yasaklanan bir ayrımcılık uygulanmamaktadır. ${ }^{58}$ Avrupa Birliği'nin İşleyişsi Hakkında Antlaşma en çok gözetilen millet kaydını (most favored nation clause) içermemektedir. Dolayısıyla, bir Üye Devletin anlaşma nedeniyle üçüncü bir AB Üye Devleti vatandaşına uyguladığı muameleyi, başka bir Üye Devletin vatandaşına uygulamamasında ayrımcılık bulunmamaktadır. ${ }^{59}$ Diğer bir deyişle, Hukuk Sözcüsü burada ayrımcılığın olup olmadığının AB Üyesi Devletlerin vatandaşlarının "o Üye Devletin vatandaşlarıyla” karşılaştırılarak tespit edileceğini, anlaşma yapılan üçüncü Üye Devlet vatandaşlarıyla karşılaştırılmayacağını savunmaktadır. $\mathrm{Bu}$ görüşünü desteklemek için ABAD'ın içtihatlarında (Cowan davas ${ }^{60}$ ile Petruhhin davas ${ }^{61}$ ) ABİHA m. 18 'in $\mathrm{AB}$ hukukunca düzenlenen bir konuda $\mathrm{AB}$ Üye Devleti vatandaşlarının "o Üye Devletin vatandaşlarıyla" tamamen eşit muameleye tabii tutulmasını zorunlu kıldığını tespit etmiş olduğunu belirtmektedir. ${ }^{62} \mathrm{AB}$ hukukunca düzenlenmeyen konularda ise devletler yapacakları anlaşmalarda farklı hak ve yükümlülükler öngörebileceklerdir.

Hukuk Sözcüsü, IYYA'lar ile oluşturulan karşıllklı haklar ve yükümlülüklerin sadece anlaşmanın tarafı olan ülkelerin yatırımcılarına uygulanacağını, ki özü gereği bunun yatırım anlaşmalarının doğal bir sonucu olduğunu savunmaktadır. Ona göre yatırımc1-devlet uyuşmazlık çözümü mekanizması ikili yatırım anlaşmasının ayrılmaz bir parçasıdır. Çünkü anlaşmada yer alan hükümlerin etkinliğinin denetimi bu sayede

58 Wathelet, para. 65.

59 Wathelet, para. 71.

60 Judgment of the Court, Case 186/87, Ian William Cowan v. Le Trésor public (Treasury), ECLI:EU:C:1989:47, 2 February 1989 (Cowan Kararı). ABAD Cowan Kararı, para. 10.

${ }_{61}$ Judgment of the Court (Grand Chamber), Case C-182/15, Aleksei Petruhhin, ECLI:EU:C:2016:630, 6 September 2016 (Petruhhin Karar1). ABAD Petruhhin Karar1, para. 29-33. Dava, uyuşturucu kaçakçıllı̆̆ suçuyla bağlantılı olarak Estonya vatandaşı olan Aleksei Petruhhin'in, Rus makamlar tarafindan çıkarılan ve Letonya makamlarına iletilen suçluların iadesi talebine ilişkindir.

62 Wathelet, para. 71-72. 
Abad'ın Achmea Kararı ve Yatırımcı-Devlet Uyuşmazlık Çözümü Açisindan...

gerçekleşmektedir. $\mathrm{Bu}$ mekanizmanın olmaması, IYYA'nın yabancı yatırımcıların teşvik edilmesi amacının sağlanamaması nedeniyle anlaşmayı anlamsız hale getirecektir. ${ }^{63} \mathrm{Bu}$ sayılan nedenlerle Hollanda-Çekoslovakya IYA'da Hollandalı yatırımcıların Slovakya'ya karşı milletlerarası tahkime gidebilmesine olanak tanıyan yatırımcı-devlet uyuşmazlık çözümü mekanizmasının ABİHA m. 18 kapsamında vatandaşlığa dayalı bir ayrımcılık oluşturmadığı görüşünü Mahkeme'ye sunmuştur. ${ }^{64}$

Görüşün 81. paragrafinda Almanya, Fransa, Hollanda, Avusturya ve Finlandiya'nın 7 Nisan 2016 tarihli resmi olmayan görüşünde (nonpaper) olduğu gibi AB-içi IYYA'ların tek bir çok taraflı yatırım anlaşmasıyla değiştirilebileceğini ve Üye Devletler ile $A B$ arasındaki yetki dağılımına göre bütün Üye Devletlerden olan yatırımcılara uygulanacak bir anlaşmanın yapılmasının önünde hiçbir engel bulunmadığı da belirtilmiştir. ${ }^{65}$

Hukuk Sözcüsü ikinci soru hakkındaki görüşünde, $\mathrm{AB}$ Antlaşmalarında belirlenen yetki dağılımını ve $\mathrm{AB}$ hukuk sisteminin özerkliğini güvenceye alan AB yargı sisteminin temel taşı olan ABİHA m. 267'nin HollandaÇekoslovakya İYA m. 8 ile oluşturulan yatırımcı-devlet uyuşmazlık çözümü mekanizmasını devre dışı bırakıp bırakmayacağ 1 konusunda, burada öngörülen tahkim mahkemesini (arbitral tribunal) ABİHA m. 267 anlamında "Üye Devletin mahkeme veya yargılama yetkisi olan makamı" olarak telakki ettiğini, dolayısıyla tahkim mahkemesinin ABAD'a ön karar için başvurmaya hakkı olduğunu ifade etmiştir. Ön karar için ABAD'a başvurabilmesi nedeniyle birinci soruda sorulan ABİHA m. 344, Üye Devletlerin Antlaşmaların yorumu ve uygulanması ile ilgili uyuşmazlıkların Antlaşmalarda öngörülenler dışında başka bir çözüm yöntemine başvurulmaması taahhüdü ile de bir uyumsuzluğun olmadığını belirtmiştir. ${ }^{66}$

Wathelet tahkim mahkemesinin ABİHA m. 267 anlamında mahkeme veya yargilama yetkisi olan bir makam olduğuna ilişkin görüşünü yerleşmiş içtihatlara dayandırmıştır. ABİHA m. 267'de yer alan “Üye Devletin

63 Wathelet, para. 75-76.

64 Wathelet, para. 82.

65 Nitekim 29 Mayıs 2020 tarihinde AB Resmî Gazetesi’nde yayımlanan, AB Üye Devletleri Arasındaki İkili Yatırım Anlaşmalarının Feshi Anlaşması'yla bu konuda önemli bir adım atılmıştır. Bu anlaşmada Enerji Şartı Anlaşması'nın 26. maddesi anlamında AB-içi yargılamalar, daha sonra $\mathrm{AB}$ ve Üye Devletler tarafından halledilmek üzere kapsam dışında bırakılmıştır. Bu konuya daha sonra ABAD, Komstroy kararında açıklık getirmiştir.

66 Wathelet, para. 85. 
mahkeme veya yargilama yetkisi olan makamı" (any court or tribunal of a Member State) ifadesi kapsamında bir yargı makamı addedilmesi için o makamın, kanun ile oluşturulup oluşturulmadığına, daimî olup olmadığına, yetkisinin zorunlu olup olmadığına, usulünün inter partes olup olmadığına, hukuk kurallarını uygulayıp uygulamadığına ve bağımsız olup olmadığına bakılmaktadır. Ayrıca söz konusu makamın önünde bir davanın görülüyor olması ve gerçekleştireceği faaliyet üzerine yargısal mahiyette bir karar doğuracak şekilde hüküm vermesi için başvurulmuş olması gerekmektedir. ${ }^{67}$

Davadaki somut durumu bu kriterlere göre irdelemek gerekmektedir. Hollanda-Çekoslovakya IY A m. 8 uyarınca oluşturulan tahkimmahkemelerinin kanunla kurulup kurulmadığı konusunda Hukuk Sözcüsü, bu madde uyarınca oluşturulan mahkemelerin yetkisini hem milletlerarası bir anlaşmadan hem de Hollanda ve Çekoslovakya devletlerinin IYA'yı onaylayan ve o devletlerin hukuk sistemlerine dahil eden kanunlarından aldığını dile getirmiştir. ${ }^{68}$

Tahkim mahkemesinin daimî olup olmadığ 1 hususunda, daimîlik kriterinin tahkim mahkemesinin kurulmasıyla ilgili olmadığı fakat tahkimin uyuşmazlık çözüm metodu olarak kurumsallaşmasının önemli olduğunu, diğer bir deyişle geçici olan tahkim heyetinin değil, tahkim yargılamasını tatbik eden tahkim kurumunun dikkate alınıp bunun daimîliğinin değerlendirilmesi gerektiğini ifade etmektedir. ${ }^{69}$ Merck Canada kararında ABAD, kurulması, hakemleri ve usul kuralları tarafların seçimine bağlı olsa da, kararını verdikten sonra sona erse de, tahkim mahkemesinin yasama yetkisine dayanarak kurulduğunu, zorunlu daimî yetkiye sahip olduğunu ayrıca milli düzenlemelerin uygulanacak usul kurallarının tanımını yapıp ve çerçevesini çizdiğini dikkate alarak, daimîlik kriterinin sağlandığına karar vermiştir. ${ }^{70}$ Achmea davasında daimî tahkim kurumlarının yer alması, örneğin, atamaların gerçekleşmemesi durumunda hakemlerin atanmasının daimî tahkim kurumu olan Stokholm

\footnotetext{
Wathelet, para. 86.

68 Wathelet, para. 90-99.

69 Wathelet, para. 100-109.

70 Order of the Court (Eighth Chamber), Case C-555/13, Merck Canada Inc. v. Accord Healthcare Ltd, Alter SA, Labochem Ltd, Synthon BV, Ranbaxy Portugal - Comercio e Desenvolvimento de Produtos Farmaceuticos, Unipessoal Lda, ECLI:EU:C:2014:92, 13 February 2014 (Merck Canada). 13 Subat 2014 tarihli Merck Canada (C 555/13, EU:C:2014:92) kararı para. 24. Wathelet para. 103-104. Bu kararda ABAD tahkim mahkemesinin daimîliğini 62/2011 sayılı Portekiz Kanunu'nun 2. maddesinden jenerik ve referans tıbbi ürünlerle ilgili endüstriyel mülkiyet haklarına ilişkin uyuşmazlıkların çözümünde tahkimin tek yol olmasından yola çıkmıştır.
} 
Abad'ın Achmea Kararı ve Yatırımcı-Devlet Uyuşmazlık Çözümü Açisindan...

Ticaret Odası'na birakılması, uygulanacak tahkim usulü olarak UNCITRAL kurallarının seçilmesi ve davanın kayıt yeri olarak 1899 ve 1907 yıllarında Uluslararası Uyuşmazlıkların Barışçıl Çözümü Hakkındaki Konvansiyonlarla Lahey'de kurulan Daimî Tahkim Mahkemesi'nin belirlenmesi Hukuk Sözcüsü'nün destekleyici argümanlarıdır. ${ }^{71}$

Hukuk Sözcüsü, tahkim mahkemesinin yetkisinin zorunlu olup olmadığ 1 konusunda 12 Haziran 2014 tarihli Ascendi Beiras Litoral e Alta, Auto Estradas das Beiras Litoral e Alta SA v. Autoridade Tributaria e Aduneira davasında ${ }^{72}$ ABAD'ın tahkim mahkemesinin kararlarının tarafları bağlayıcı olduğuna ve yetkisinin kanunlardan alması ve tarafların uyuşmazlıklarını tahkime götürme isteklerini önceden ifade etmelerinden değil, kanunlardan kaynaklandığına dayanarak, vergi mükellefi davacı uyuşmazlığını vergi tahkimine götürdüğünde tahkim mahkemesinin vergilendirme ve gümrükleme konularında zorunlu yetkisinin olduğuna karar vermesini destekleyici argüman olarak ileri sürmüştür. ${ }^{73}$ Hollanda-Çekoslovakya İYA m. 8/7, bu madde uyarınca teşkil eden tahkim mahkemesinin kararlarının nihai ve uyuşmazlığın taraflarını bağlayıcı olduğunu düzenlemektedir. İYA m. 8/2'de ise uyuşmazlığın başvuru tarihinden itibaren altı ay içerisinde dostane çözüm yollarıyla çözülememesi durumunda Âkit Devletlerin, yatırımcı ile devlet arasındaki uyuşmazlıkların tahkim mahkemesine götürülebileceğine onay verdiği ifade edilmektedir. Hukuku sözcüsü burada yatırımcıya verilen devlet mahkemelerinde veya tahkim mahkemesinde davanın açılma imkânı verilmesinin tahkim mahkemesinin yetkisinin zorunlu mahiyetini etkilemediğini, çünkü Ascendi Beiras Litoral e Alta, Auto Estradas das Beiras Litoral e Alta SA v. Autoridade Tributaria e Aduneira davasında vergi mükellefinin de bu seçimlik hakka sahip olduğunu belirtmiştir. Slovakya Cumhuriyeti'nin de Portekiz Cumhuriyeti gibi tahkime rızasını önceden verdiğini ve IYYA'ya uygun şekilde teşkil edilen tahkim mahkemesinin yetkisinin m. 8/2 uyarınca Üye Devlet ve yatırımcıyı bağlayıcı olduğunu ifade ederek, bu tahkim mahkemelerinin zorunlu yetki kriterini taşıdığını ileri sürmüştür. ${ }^{74}$

\footnotetext{
71 Wathelet, para. 107-108.

72 Judgment of the Court (Second Chamber), Case C-377/13, Ascendi Beiras Litoral e Alta, Auto Estradas das Beiras Litoral e Alta SA v. Autoridade Tributaria e Aduneira, ECLI:EU:C:2014:1754, 12 June 2014 (Ascendi Beiras Litoral e Alta, Auto Estradas das Beiras Litoral e Alta).

3 Wathelet, para. 112-113.

74 Wathelet, para. 110-119.
} 
Hollanda-Çekoslovakya İYA m. 8 uyarınca teşkil eden tahkim mahkemelerinin usulünün inter partes olup olmadığı hususunda, m. 8/5 uyarınca tahkim mahkemesinin usulünü UNCITRAL tahkim kurallarını uygulayarak tespit edeceği düzenlenmiştir. İYA'nın yürürlüğe girdiği tarihte geçerli olan 1976 versiyonu m. 15/1' $\mathrm{e}^{75}$ ve diğer ilgili maddelere göre tahkim mahkemesinin, taraflara eşit muamele ettiği ve yargılamanın bütün aşamalarında tarafların davalarını sunmaları için fırsat verdiği müddetçe, tahkim yargılamasını UNCITRAL tahkim kurallarına tabii olarak uygun gördüğü şekilde yürütebileceğini düzenlemektedir. ${ }^{76}$ Tahkim mahkemelerinin uyuşmazlığın çözümünde hukuk kurallarını uygulayıp uygulamadığı kriterine göre incelendiğinde ise İYA'nın 8. maddesinin 6. fikrasında tahkim mahkemesinin hukuk kuralları temelinde karar vereceğinin düzenlendiği ve hak ve nesafet kurallarının uygulanamayacağı dikkate alındığında bunun da

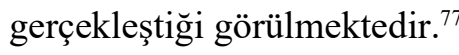

Son kriter olan mahkemenin bağımsız olup olmadığı konusunda ise, UNCITRAL Tahkim Kuralları'nın hakemlerin bağımsızlığına ve tarafsızlığına gölge düşürebilecek haklı şüphe olması durumunda bunu bildirme sorumluluğu bulunduğu ve hakemin reddi imkânı ile mahkemenin bağımsızlığını güvence altına aldığ söylenebilmektedir. ${ }^{78} \mathrm{Bu}$ argümanlara dayanarak, Hukuk Sözcüsü, IYAm. 8 uyarınca teşkil edilen tahkim mahkemesinin ABİHAm. 267 anlamında "mahkeme veya yargılama yetkisi olan makam" olduğunu savunmuştur. ${ }^{79}$ IYA m. 8 uyarınca teşkil edilen tahkim mahkemesinin "Üye Devletin mahkeme veya yargılama yetkisi olan makamı" olduğunu ise Üye Devletler arasında uluslararası anlaşma ile kurulan Benelüks Mahkemesi'nin ve birden fazla Üye Devletin ortak mahkemelerinin, diğer Üye Devlet mahkemeleri veya yargılama yetkisi olan makamları gibi ABAD'a ön karar için başvurmak ve sorularını yöneltmek için önünde hiçbir engelin bulunmadığını ifade eden 4 Kasım 1997 tarihli Parfums Christian Dior davasına ${ }^{80}$ dayandırmıştır. ${ }^{81}$

\footnotetext{
75 Benzer düzenleme 2010 ve 2013 versiyonunda m. 17'de bulunmaktadır.

76 Wathelet, para. 120-122.

77 Wathelet, para. 123.

Wathelet, para. 124-125.

Wathelet, para. 126

80 Judgment of the Court, Case C-337/95, Parfums Christian Dior SA and Parfums Christian Dior BV v. Evora BV, ECLI:EU:C:1997:517, 4 November 1997 (Parfums Christian Dior). 4 Kasım 1997 tarihli, Parfums Christian Dior (C337/95, EU:C:1997:517) kararı, para. 21.

81 Wathelet, para. 128-129.
} 
Abad'ın Achmea Kararı ve Yatırımcı-Devlet Uyuşmazlık Çözümü Açisindan...

Böylece IYA m. 8 uyarınca teşkil edilen tahkim mahkemesinin "Üye Devletin mahkeme veya yargılama yetkisi olan makamı” olduğu sonucuna varmıştır.

Ayrıca bazı tahkim heyetleri gördükleri davalarda soruları hakkında ön karar için ABAD'a başvurmuşlardır. Bunlardan bazıları reddedilmiştir ${ }^{82}$ ancak bazı başvurular ise kabul edilmiş ve bu konularda karar verilmiştir. ${ }^{83}$ Buna dayanarak Hukuk Sözcüsü, kişilerle devlet arasında olan tahkim yargılamalarında kabul edilebilirlik kriterinin önünün açıldığını gösteren belirtilerin açıkça mevcut olduğunu ifade etmiştir.

Önkarar için başvuran mahkemenin diğerbir sorusu ise ABİHAm. 344'ün, Hollanda-Çekoslovakya İYA m. 8 gibi yatırımcı-devlet uyuşmazlıklarının tahkim mahkemesinde çözümüne imkân tanıyan AB-içi IYYA'larda yer alan hükümleri engelleyecek şekilde yorumlanıp yorumlanmayacağıdır. Hukuk Sözcüsü, Mahkeme'nin IYYA m. 8 uyarınca teşkil edilen tahkim mahkemesinin ABİHA m. 267 anlamında mahkeme veya yargilama yetkisi olan makam olarak kabul etmesi durumunda, AB'nin Avrupa İnsan Hakları Mahkemesine Katılımı hakkında 2/13 Sayılı Görüşü’nde ${ }^{84}$ belirttiği üzere,

82 Judgment of the Court, Case C-102/81, Nordsee Deutsche Hochseefischerei GmbH v. Reederei Mond Hochseefischerei Nordstern AG \& Co. KG and Reederei Friedrich Busse Hochseefischerei Nordstern AG \& Co. KG., ECLI:EU:C:1982:107, 23 March 1982 (Nordsee). Judgment of the Court (Fourth Chamber), Case C-125/04, Guy Denuit and Betty Cordenier v. Transorient - Mosaïque Voyages et Culture SA, ECLI:EU:C:2005:69, 27 January 2005 (Denuit and Cordenier). 23 Mart 1982 tarihli Nordsee (102/81, EU:C:1982:107) ve 27 Ocak 2005 tarihli Denuit and Cordenier (C-125/04, EU:C:2005:69) kararı gibi.

83 Judgment of the Court, Case 109/88, Handels- og Kontorfunktionærernes Forbund i Danmark (Union of Commercial and Clerical Employees, Denmark) v. Dansk Arbejdsgiverforening (Danish Employers' Association), acting on behalf of Danfoss A/S, ECLI:EU:C:1989:383, 17 October 1989 (Handels-og Kontorfunktionærernes Forbund i Danmark). 17 Ekim 1989 tarihli Handels-og Kontorfunktionærernes Forbund i Danmark (109/88, EU:C:1989:383); 12 Haziran 2014 tarihli Ascendi Beiras Litoral e Alta, Auto Estradas das Beiras Litoral e Alta (C 377/13, EU:C:2014:1754) ve 13 Şubat 2014 tarihli Merck Canada (C 555/13, EU:C:2014:92) kararı gibi. Wathelet, para. 87.

84 Avrupa Komisyonu'nun 4 Kasım 1950 tarihinde Roma'da imzalanan İnsan Hakları ve Temel Özgürlüklerin Korunmasına İlişkin Sözleşme’ye (Avrupa İnsan Hakları Sözleşmesi’ne) Avrupa Birliği'nin katılımını sağlayan taslak anlaşmanın AB Antlaşmalarıyla uyumlu olup olmadığına ilişkin ABAD'ın görüşünü almak için yaptığı başvuru sonucunda verilen 2/13 Sayılı Mahkeme Görüşü. Opinion 2/13 of the Court (Full Court) Opinion pursuant to Article 218(11) TFEU, EU:C:2014:2454, 18 December 2014 (2/13 Sayılı Görüş). Görüşün tam metni için bkz. <https://eur-lex.europa.eu/legal-content/EN/TXT/PDF/?uri=CELEX:62013 CV0002\&from $=\mathrm{EN}>$ Erişim Tarihi 15.11.2021.

Bu görüșün 176. paragrafında ABİHA m. 267'de yer alan mahkemeler özellikle de ABAD ile mahkemeler veya yargılama yetkisi olan makamlar arasında diyaloğu sağlayan ön karar prosedürü ile $\mathrm{AB}$ hukukunun yeknesak olarak yorumlanmasının güvenceye alınması sağ- 
tahkim mahkemeleri ile $\mathrm{ABAD}$ arasında diyaloğun mümkün olacağını, tahkim mahkemelerinin ABAD'ın içtihatlarında ortaya konan ilkelere ${ }^{85}$ uymak zorunda olduklarını ve $\mathrm{AB}$ hukukunu uygulamak durumunda kalacaklarını ifade etmiştir. Böylece milletlerarası tahkime gidilmiş olması ile ABİHA m. 344 veya $A B$ Antlaşmalarınca belirlenen yetki dağılımı dolayısıyla $A B$ hukuk sisteminin özerkliğine zarar gelmeyecektir. Tahkim mahkemelerinin buna uymaması durumunda verdikleri kararlar kamu düzenine aykırılık gerekçesiyle iptal edilecektir. ${ }^{86}$

Hukuk Sözcüsü Mahkeme'nin IYYA m. 8 uyarınca teşkil edilen tahkim mahkemesinin ABİHA m. 267 anlamında mahkeme veya yargılama yetkisi olan makam olarak kabul etmemesi durumunda ise ABİHA m. 344'un IYYA m. 8'in uygulanmasını engelleyip engellemediği ve gerekli olması durumunda IYYA m. 8 'in $\mathrm{AB}$ Antlaşmalarınca belirlenen yetki dağılımıyla ve $\mathrm{AB}$ hukuk sisteminin özerkliğiyle uyumlu olup olmadığı sorularının da değerlendirilmesinin gerekli olduğunu düşünmektedir. ${ }^{87}$ Bunu cevaplamak için üç soru sormaktadır. ABİHA m. 344'e göre Üye Devletlerin, AB Antlaşmaları'nın yorumu veya uygulanması ile ilgili bir uyuşmazlık konusunda, Antlaşmalar'da öngörülenler dışında bir çözüm yöntemine başvurmamayı taahhüt ettiği düzenlenmektedir. Bu nedenle Hukuk Sözcüsü öncelikle IYYA m. 8'de yer alan yatırımc1 ile Üye Devlet arasındaki bir uyuşmazlığın ABİHA m. 344 kapsamına girip girmediğini sormaktadır. Eğer bu sorunun cevabı olumlu ise yatırımc1 ile Üye Devlet arasındaki böyle bir uyuşmazlığın konusunun ABİHA m. 344 anlamında $\mathrm{AB}$ Antlaşmalarının yorumu veya uygulanmasına ilişkin olduğu

landığı ve böylece $\mathrm{AB}$ hukukunun tutarlılığına, tam etkinliğine, özerkliğine ve sonuç olarak Antlaşmalarla oluşturulan bu hukukun hususi mahiyetinin sağlanmasına hizmet edilmekte olduğu belirtilmiştir.

85 Örneğin, AB hukukunun Üye Devletlerin hukukuna ve Üye Devletler arasında verilen milletlerarası taahhütlere üstünlüğü, kendilerine ve vatandaşlarına birçok kuralın doğrudan etki ettiği, AB'nin üzerine kurulduğu ortak değerlerin tanınacağına olan aralarındaki karşılıklı güven ve $\mathrm{AB}$ hukukunun tam uygulanması ve $\mathrm{AB}$ hukukuna riayet edilmesi gibi ilkelere uymak. Hukuk Sözcüsü yatırımcı/AB vatandaşı ve Üye Devletler arasındaki uyuşmazlıkların görüldüğü tahkim mahkemelerinin bazılarında (örneğin, Achmea B.V. v. Slovak Republic (UNCITRAL) (PCA Case No 2008-13); Electrabel S.A. v. Hungary (ICSID Case No $\mathrm{ARB} / 07 / 19)$; Charanne B.V. and Construction Investments S.à.r.l. v. Kingdom of Spain (SCC Case No 062/2012); RREEF Infrastructure (G.P.) Limited and RREEF Pan-European Infrastructure Two Lux S.à.r.l. v. Kingdom of Spain (ICSID Case No ARB/13/30)) halihazırda $\mathrm{AB}$ hukukunun üstünlügünün kabul edildiğini belirtmiştir. Wathelet, para. 134, dipnot 99.

86 Wathelet, para. 133-134.

87 Wathelet, para. 136. 
Abad'ın Achmea Kararı ve Yatırımcı-Devlet Uyuşmazlık Çözümü Açisindan...

şeklinde vasıflandırılmasının mümkün olup olmadığı sorusunun cevaplanması gerekecektir. Diğer bir deyişle, uyuşmazlık konusunun Antlaşmaların yorumlanmasıyla veya uygulanmasıyla ilgili olup olmadığının cevabı aranacaktır. Son olarak, bu iki sorudan birinin cevabı olumsuz ise IYYA'nın amacı dikkate alınarak, bunun AB Antlaşmalarınca belirlenen yetki dağılımına, dolayısıyla $\mathrm{AB}$ hukuk sisteminin özerkliğine zarar verecek bir etkiye sahip olup olmadığının yanıtlanması gerekecektir. ${ }^{88}$

Hukuk Sözcüsü'ne göre, daha önce verilen kararlar 1şı̆̆ında uluslararası bir anlaşmanın AB Antlaşmalarınca belirlenen yetki dağılımına ve ABAD'ın denetimini güvence altına aldığı $\mathrm{AB}$ hukuk sisteminin özerkliğine etki etme imkânı bulunmamaktadır. Üye Devletler AB Antlaşmalarının yorumu veya uygulanmasına ilişkin uyuşmazlıkları Antlaşmalar'da öngörülenler dışında bir çözüm yoluna götürmemeyi taahhüt etmişlerdir. Bu hüküm özel olarak Üye Devletlerin $\mathrm{ABA}$ m. 4/3'ten doğan sadakat yükümlülügünün bir yansıması olarak anlaşılmalıdır. Slovakya ve Komisyon'un iddia ettiği gibi açıç̧a Üye Devletler ifadesi geçmemesi nedeniyle bu hükmün geniş yorumlanarak Üye Devletler ve kişiler arasındaki uyuşmazlıklar bakımından da uygulanması doğru değildir. ABAD kararlarında da Üye Devletler arasındaki ve Üye Devletlerle AB arasındaki uyuşmazlıkların ABİHA m. 344 kapsamına girdiği görülmektedir. Ancak kişiler arasındaki uyuşmazlıklar bu kapsamda değildir. ${ }^{89} \mathrm{Bu}$ noktada Wathelet kişilerin Avrupa İnsan Hakları Mahkemesinde Üye Devletler aleyhine dava açmasını örnek olarak göstermektedir. AB'nin Avrupa İnsan Hakları Sözleşmesi'ne (AİHS) katılımını sağlayan taslak anlaşmanın AB Antlaşmalarıyla uyumlu olup olmadığına ilişkin 2/13 Sayılı Mahkeme Görüşünde bu husus incelenmiş ve sadece Üye Devletler arasında ve Üye Devletlerle AB arasındaki uyuşmazlıkların ABİHA m. 344 kapsamına girdiği belirlenmiştir. ${ }^{90}$

Esas davaya konu olan kararı veren tahkim mahkemesi de Slovakya ve Komisyonun iddialarını incelemiş ve yatırımcılar ile IYYA'ya taraf olan devletler

88 Wathelet, para. 137

89 Wathelet, para. 138-148.

90 Opinion 2/13 (Accession of the Union to the ECHR) of 18 December 2014(EU:C:2014:2454), para. 201-214. Bu kısımda ayrıca AİHS'e katılmayla birlikte bunun AB hukukunun bir parçası olacağı, dolayısıyla Üye Devletler arasında veya Üye Devletler ile AB arasında AİHS'e riayet etme hususunda uyuşmazlık çıkması durumunda ABAD'ın AB hukuku söz konusu olduğundan münhasır yetkisinin bulunduğu ifade edilmiștir. Buradan yola çıkarak uluslararası anlaşmalara dayanarak kişilerin Üye Devletlere karşı açtıkları davaların ABİHA m. 344 kapsamına girmediği açıkça anlaşılmaktadır. 
arasındaki uyuşmazlıkların ABİHA m. 344 kapsamına girmediğini ABAD'ın 30 Mayıs 2006 tarihli MOX Plant davası kararına ${ }^{91}$ dayanarak savunmuştur. Buna göre ABİHA m. 344 ve sadakat ilkesinden dolayı ABAD'ın iki Üye Devlet arasındaki uyuşmazlıklar hakkında münhasır yetkisi olduğunu, yani IYA m. 10 kapsamındaki uyuşmazlıklar hakkında bu kararın emsal niteliği taşıdığını, ancak iki devlet arasında olmayıp yatırımcı-devlet arasında olan uyuşmazlıklara ABİHA m. 344'ün ve sadakat ilkesinin uygulanamayacağını ifade etmiştir. ${ }^{92}$

Komisyon'un yazılı görüşünde yatırımcılar ile Üye Devletler arasındaki uyuşmazlıklarda yatırımcının aslında kendi hakkını kullanmadığını ancak tabiiyetinde olduğu devlete IYYA'nın verdiği bir hakkı kullandığı iddiasını, Hukuk Sözcüsü, Komisyon'un atıf yaptığı tahkim davalarıyla çelişmesi, genelgeçer bir kabule sahip olmaması, uluslararası anlaşmaların belirli koşullarla kişilere haklar vermesi ve IYYA'ların da açıkça yatırımcılardan bahsederek doğrudan onlara haklar vermesine dayanarak eleştirmektedir. ${ }^{93}$ Hukuk Sözcüsü bu argümanlarla İYA m. 8'deki gibi yatırımcı ile Üye Devlet arasındaki uyuşmazlıkların ABİHA m. 344 kapsamına girmediği sonucuna varmaktadır. Uyuşmazlık konusunun Antlaşmaların yorumlanmasıyla veya uygulanmasıyla ilgili olup olmadığı sorusunun cevaplanması, aslında ilk sorunun yanıtı nedeniyle gereksiz olmaktadır. Ancak Hukuk Sözcüsü Mahkeme'nin aynı kanaatte olmama ihtimaline binaen bu soruyu da incelemiştir. ${ }^{94}$ Ona göre, Slovakya ve Komisyon'un örnek olarak gösterdiği 2/13 Sayılı Mahkeme Görüşü’nde ve Komisyon v. İrlanda kararında ${ }^{95}$ kriter olarak belirlenen durumun aksine Avrupa Birliği IYYA'nın tarafı olmaması nedeniyle IYA AB hukukunun bir parçası haline gelmemiştir. Dolayısıyla ABİHA m. 344'te güvence altına alınan ABAD'ın münhasır yetkisi etkilenmemektedir. ${ }^{96}$

$\mathrm{AB}$ hukukunun, İYA m. 3/5, 8/6 veya tahkim yeri hukuku olan Alman hukuku veyahut diğer düzenlemelere dayanarak uygulanacak hukuk olması

\footnotetext{
91 Judgment of the Court (Grand Chamber), Case C-459/03, Commission of the European Communities v. Ireland, ECLI:EU:C:2006:345, 30 May 2006 (MOX Plant).

92 Eureko B.V. v. The Slovak Republic, Award on Jurisdiction, Arbitrability and Suspension, PCA Case No. 2008-13, 26 October 2010, para. 276.

93 Wathelet, para. 154-159.

94 Wathelet, para. 159-228.

95 Judgment of the Court (Grand Chamber), Case C-459/03, Commission of the European Communities v. Ireland, ECLI:EU:C:2006:345, 30 May 2006.

96 Wathelet, para. 165-168.
} 
Abad'ın Achmea Kararı ve Yatırımcı-Devlet Uyuşmazlık Çözümü Açisindan...

durumunda ise bu durum yatırımcı ile devlet arasında olan uyuşmazlığın AB Antlaşmalarının yorumu veya uygulanmasıyla ilgili olması sonucunu doğurmamaktadır. Çünkü tahkim mahkemesinin yargılama yetkisi İYA’nın ihlali ile sınırlandırılmıştır ve $\mathrm{AB}$ hukukunun ihlali iddiaları hakkında karar verme yetkisi bulunmamaktadır. Tahkim mahkemesi Üye Devletin AB hukukunca var olan yükümlülüklerini ihlal edip etmediği hususunda karar vermemektedir, devletin eylem ve işlemlerinin İYA'yı ihlal edip etmediğini ilgili unsurlardan biri olarak AB hukukunu da dikkate alarak IYA kapsamında değerlendirmektedir. ${ }^{97}$ Taraflar da tahkim mahkemesinin uyuşmazlığın esasına ilişkin kararını veya gerekçesini etkileyebilecek $\mathrm{AB}$ hukuku hükümlerine dayanmamıştır. ${ }^{98}$ Ayrıca IYYA'nın kapsamı ve gösterdiği hukuk kuralları AB Antlaşmalarıyla aynı değildir. Hukuk Sözcüsü'ne göre, İYA'nın kapsamı $\mathrm{AB}$ Antlaşmalarından daha geniştir ${ }^{99}$, İYA'de yer alan hukuk kurallarından bazılarının $\mathrm{AB}$ hukukunda dengi yoktur ${ }^{100}$ ve bazı kurallar ${ }^{101}$ kısmen $\mathrm{AB}$ hukuku ile aynı konuda olsa da bunlar AB Antlaşmalarıyla uyumludur. ${ }^{12}$ Dolayısıyla, IYYA kapsamına giren söz konusu uyuşmazlık, AB Antlaşmalarının

97 Wathelet, para. 175.

98 Wathelet, para. 178

99 Wathelet, AB hukukunu ihlal etmeyen bu nedenle yatırımcının kayıplarının tazmini için dava açamadığı ancak ikili yatırım anlaşmaları kapsamında bunu gerçekleştirebildiği sermaye kontrolü tedbirlerine karşı açılan Theodoros Adamakopoulos and others v. Güney Kıbrıs Rum Yönetimi (ICSID Case No ARB/15/49), dolaylı kamulaştırma ve keyfi ve ayrımcı tedbirlere karşı açılan Marfin Investment Group Holdings S.A., Alexandros Bakatselos and others v. Güney Kıbrıs Rum Yönetimi (ICSID Case No ARB/13/27) gibi davaları örnek göstermiştir. Şirketlerde azınlık haklarının korunmasında ve doğrudan vergilendirme konusunda da İYA'nın daha fazla koruma sağladığını ifade etmiştir.

100 Örneğin, en çok gözetilen millet kaydı, şemsiye hükmü, gün batımı hükmü, yatırımc1-devlet uyuşmazlık çözümü mekanizması olarak milletlerarası tahkime gitme imkânı tanıyan hüküm gibi.

101 Hukuk Sözcüsü'ne göre, İYA'da yatırımcıya tam koruma ve güvenliğin sağlanması, adil ve hakkaniyete uygun muamelede bulunulması, yatırımcının haksız kamulaştırmaya karşı korunmasına ilişkin hükümler AB hukukuna aykırı olmadan, kapsam olarak AB Antlaşmalarında yer alan hükümlerden daha geniştir. Örneğin, Avrupa Birliği Temel Haklar Şartı m.17'de (Charter of Fundamental Rights of the European Union) yer alan mülkiyet hakkının korunmasına dair hükümde mülkiyetin kamulaştırılması durumunda zararı için makul sürede, adil (fair) bir tazminatın ödeneceği belirtilmekteyken, İYA m.5/c'de ödenecek tazminatın yatırımın gerçek değerinde, davacı tarafından kabul edilen konvertibl para birimi üzerinden, davacının belirlediği ülkeye gecikmeksizin çıkarılabilecek şekilde ödeneceği ifade edilmektedir. Charter of Fundamental Rights of the European Union, OJ C 326, 26.10.2012.

102 Wathelet, para. 181-228. 
yorumlanması veya uygulanmasına ilişkin bir uyuşmazlık değildir. ${ }^{103}$

Hukuk Sözcüsü bu iki soruyu da tahlil ettikten sonra IYYA'nın amacını dikkate alarak, bunun $\mathrm{AB}$ Antlaşmalarınca belirlenen yetki dağılımına, dolayısıyla $\mathrm{AB}$ hukuk sisteminin özerkliğine zarar verecek bir etkiye sahip olup olmadığ 1 hususunu ele almıştır. Wathelet, ABA m. 4/3 uyarınca Üye Devletlerin kendi ülkelerinde $\mathrm{AB}$ hukukunun uygulanmasını ve bu hukuka riayet edilmesini sağlamakla yükümlü olduklarını, $\mathrm{AB}$ hukukunun yorumunun yeknesak ve uyumlu olarak yapılması amacıyla AB Antlaşmalarıyla oluşturulan yarg1 sisteminde $\mathrm{AB}$ hukukunun Üye Devletlerde tam olarak uygulanmasının ve kişilerin $\mathrm{AB}$ hukukundan kaynaklanan haklarının yargısal olarak korunmasının milli mahkemelere ve ABAD'a bırakıldığını belirtmiştir. ${ }^{104} \mathrm{Bu}$ anlamda yatırımcıların İYA kapsamında milletlerarası tahkime gitmesinin, ABAD'n tahkim mahkemelerinin ABİHA m. 267 anlamında Üye Devletlerin mahkemeleri veya yargılama yetkisi olan makamları olmadığına karar vermesi durumunda bile, AB Antlaşmalarınca belirlenen yetki dağılımına ve $\mathrm{AB}$ hukuk sisteminin özerkliğine zarar vermediğini düşünmektedir. Çünkü İYA m. 8'e göre tahkim mahkemeleri tarafindan verilen kararlar milli mahkemelerin incelemesinden geçecektir. $\mathrm{Bu}$ inceleme ya tahkim yeri mahkemelerinde hakem kararına karşı açılabilecek iptal davası veya hakem kararının tanınması veya tenfizinin istendiği ülke mahkemelerinde tanıma ve tenfiz talebine itiraz ${ }^{105}$ olarak karşımıza çıkabilecektir. ${ }^{106}$ Tahkimde AB hukukuna ilişkin bir meselenin ortaya çıkması durumunda, bu milli mahkemelerin veya yargılama yetkisi olan makamların önüne geldiğinde bunun hakem kararını incelerken uygulamaları gereken $\mathrm{AB}$ hukuku hükümlerinin geçerliliğinin değerlendirilmesi veya yorumun alınması için ABİHA m. 267 kapsamında ABAD'a gönderilmesine gerek olup olmadığına karar vermeleri gerekmektedir. ${ }^{107}$ Görüldüğü üzere, ister iptal

103 Wathelet, para. 228.

104 Wathelet, para. 229-234.

105 Bütün AB üyesi devletler Yabancı Hakem Kararlarının Tanınması ve İcrası Hakkındaki New York Konvansiyonuna taraftır. Konvansiyon uyarınca milli mahkemeler hakem kararlarının tanınması ve tenfizini 5. maddede yer alan hususların bulunması, örneğin tanıma ve tenfizin o devletin kamu düzenine dolayısıyla $\mathrm{AB}$ kamu düzenine aykırı olması, durumunda reddedebilir.

106 Wathelet, para. 237-239.

107 Wathelet, para. 240-241. Bu yönde kararlar için bkz. 23 Mart 1982 tarihli Nordsee (102/81, EU:C:1982:107) kararı para. 14, 15; Judgment of the Court, Case C-393/92, Gemeente (Municipality of) Almelo and others v. Energiebedrijf Ijsselmij NV, ECLI:EU:C:1994:171, 27 
Abad'ın Achmea Kararı ve Yatırımcı-Devlet Uyuşmazlık Çözümü Açisindan...

davası, ister tanıma ve tenfiz talebine itiraz yoluyla olsun, Üye Devletlerin mahkemelerinin veya yargılama yetkisi olan makamlarının AB hukukunun yeknesak yorumlanmasını sağlaması mümkündür. Achmea davasında tahkim yeri Frankfurt, Almanya'dır ve tahkim mahkemesinin verdiği karara karşı Alman Hukuk Usulü Kanunu'na göre Alman mahkemelerinde iptal davası açılması imkânı bulunmaktadır, ki dava bu kapsamda ABAD'ın önüne gelmiştir. ${ }^{108}$ Diğer ihtimalleri gözettiğimizde de, örneğin, hakem kararının tanıma ve tenfizi talebiyle bir Üye Devlette başvurulmuş olması durumunda, bu devletin mahkemeleri kararın tanıma ve tenfizine karar vermeden önce $\mathrm{AB}$ hukuku ile uyumlu olduğunu garanti etmekten sorumlu olacaktır. ${ }^{109}$ Komisyonun risk olarak gördüğü başka bir ihtimal ise tahkim yerinin üçüncü bir ülke olması veya hakem kararının tanıma ve tenfizi talebinin üçüncü ülkede yapılması durumudur ki bu durumda hakem kararının AB hukukuna uyumlu olup olmadığı incelenemeyecektir. ${ }^{110}$ Komisyon bu noktada AB-içi İYA'larda milletlerarası tahkim için ICSID'in seçilmesi durumunda hakem kararının taraflar için bağlayıcı olacağını ve ICSID Konvansiyonu'nda yer alan imkânlar dışında temyiz veya başka bir imkâna başvurulmasının mümkün olmadığını ve Üye Devlet mahkemelerinin ICSID hakem kararlarının AB hukukuna uyumunu inceleyebileceği herhangi bir hukuki yöntem bulunmadığını ifade etmiştir. Hukuk Sözcüsü, Komisyon'un bu endişelere sahip olmasına rağmen AB-Singapur Serbest Ticaret Anlaşması - Yatırım Koruma Anlaşması Bölüm 3 m. 9.16'da ICSID' in tahkim kurumu olarak seçilmesine anlam verememiştir. ${ }^{111}$ Söz konusu Achmea v. Slovakya davasında ise böyle bir durum söz konusu değildir. Taraflarca kayıt mercii olarak Lahey'de bulunan Daimî Tahkim Mahkemesi, tahkim yeri olarak Frankfurt seçilmiştir ve üçüncü bir ülkede tanıma ve tenfiz talebi bulunmamaktadır. Bir Üye Devletin mahkeme veya yargılama yetkisi olan makamı önünde görülen hakem kararının iptali davası söz konusudur. ${ }^{112}$ Hakem kararının esasının AB hukukuna aykırılığı da mesele olarak ileri sürülmemektedir. Başvurucu mahkemede Slovakya tarafından IYYA kapsamında oluşturulan uyuşmazlık çözüm mekanizmasının AB

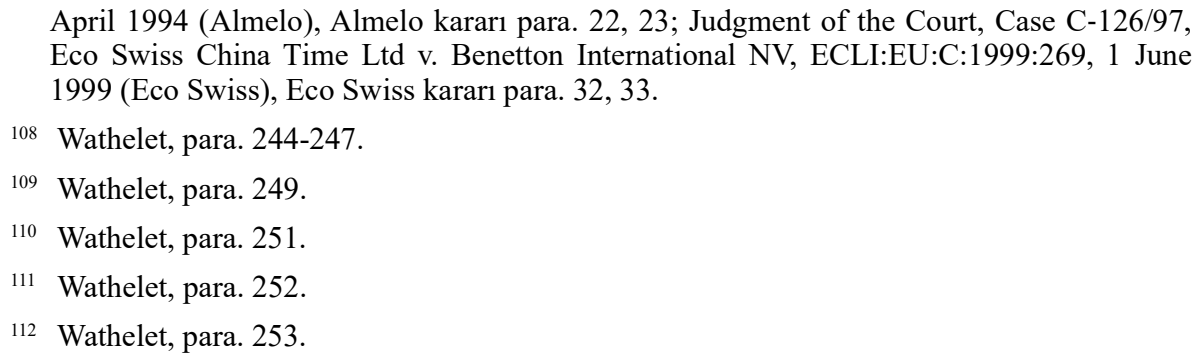


Antlaşmalarına aykırı olduğu iddia edilmektedir. Hukuk Sözcüsü'ne göre, bir hakem kararının AB Antlaşmalarına aykırı olması durumunda bunu herhangi bir Üye Devletin iptal davası veya tanıma ve tenfiz talebine itiraz ile ileri sürmemesi durumunda dahi ABİHA m. 258 ve m. 260 uyarınca, bunu göz ardı eden Üye Devlete karşı Komisyon'un dava açma imkânı bulunmaktadır. ${ }^{113}$ Komisyon ve bazı Üye Devletlerin, verilecek hakem kararlarının AB hukukuna aykırı olabileceğine dayandıkları görüşleri milletlerarası yatırım tahkiminin yanında milletlerarası ticari tahkimde de bulunan bir risktir. Ancak ABAD kararlarında ${ }^{114}$ kişiler arasında $\mathrm{AB}$ rekabet hukuku meselelerinin görüldüğü tahkim davalarında verilen kararların geçersiz olduğu iddia edilmemiştir. ${ }^{115}$ Kişiler arasındaki milletlerarası tahkim AB Antlaşmalarınca belirlenen yetki dağılımına ve $\mathrm{AB}$ hukuk sisteminin özerkliğine zarar vermiyorsa yatırımcılar ve devletler arasındaki milletlerarası tahkimde de bu söz konusu olmayacaktır. Wathelet'e göre, devletlerin taraf olduğu tahkimler genellikle kamuya açık olduğundan daha şeffaf bir şekilde yürütüldügü için $\mathrm{AB}$ Antlaşmalarının ihlal edilip edilmediği daha kolay tespit edilebilecek ve ABİHA'dan kaynaklanan yükümlülüklerini yerine getirmemeleri durumunda dava açılabilecektir. ${ }^{116}$ Diğer bir iddia ise tahkim yargılamasının Üye Devletler arasındaki karşılıklı güven ilkesini ihlal ettiğidir. Hukuk Sözcüsü tahkime ancak Üye Devletlerin onayı ile gidilebileceğini ve Achmea şirketinin de Üye Devletler tarafından sunulan seçeneklerden biri olan tahkimi seçtiğini belirtmektedir. Bu durum duruşmalar esnasında Hollanda Hükümetinin ifade ettiği şekliyle yatırımcıdevlet uyuşmazlık çözüm metodu olarak milletlerarası tahkime gidilmesinin, Hollanda veya Slovakya'nın diğer tarafin $\mathrm{AB}$ hukukuna veya kabul ettikleri temel haklara uyup uymayacağ 1 konusunda tereddüdünün bulunduğunu hiçbir şekilde ima etmemektedir. ${ }^{17}$ İkili yatırım anlaşmalarında yer alan bu mekanizma, milli mahkemelerde yatırımcıların uluslararası anlaşmalardaki hükümlere dayanarak iddialarını ileri sürmelerinin garantisi olmadığ 1 için,

\footnotetext{
113 Wathelet, para. 254-255.

114 Bu yönde bkz. Eco Swiss kararı (C-126/97, EU:C:1999:269); Genentech kararı, Judgment of the Court (First Chamber), Case C-567/14, Genentech Inc. v. Hoechst GmbH and SanofiAventis Deutschland GmbH, ECLI:EU:C:2016:526, 7 July 2016 (Genentech). Eco Swiss kararının AB-içi yatııım anlaşmalarına dayanan tahkimler üzerindeki etkisi için bkz. Kazım Sedat Sirmen, "The Concept of Public Policy in the Eco Swiss Decision of the Court of Justice of the European Union and Its Impact on the Intra-EU Investment Treaty Arbitrations", 2021, 12(2), Inonu University Law Review, s. 438-449.

115 Wathelet, para. 257-259.

116 Wathelet, para. 259.

117 Wathelet, para. 261-263.
} 
Abad'ın Achmea Kararı ve Yatırımcı-Devlet Uyuşmazlık Çözümü Açisindan...

yatırımcılara devlete karşı IYA tarafından sağlanan haklarına dayanarak dava açmaları için bir mahkeme (forum) sağlamaktadır. Wathelet'e göre bu imkân, Üye Devletler arasında bir güvensizlikten kaynaklı değil, yatırımcının akdedilen ikili yatırım anlaşmasından doğan haklarını ileri sürebileceği ve anlaşmanın tam etkinliğinin sağlanacağı tek yolun bu konuda ihtisaslaşmış bir mahkeme oluşturulmasıyla mümkün olmasından kaynaklanmaktadır. ${ }^{18}$

Hukuk Sözcüsü, görüşünde ifade ettiği bütün bu argümanlarla İYA m. 8 'in ABİHA m. 344 ile uyumlu olduğu ve AB Antlaşmalarınca belirlenen yetki dağılımına ve $A B$ hukuk sisteminin özerkliğine zarar vermediği görüşündedir. ${ }^{119}$ ABAD'ın ABİHA m. 18, m. 267 ve m. 344'ün bir Üye Devletin Avrupa Birliği'ne katılmasından önce imzalanan ikili yatırım anlaşmasına dayanarak oluşturulan ve bir Üye Devlet yatırımcısının diğer Üye Devletteki yatırımına ilişkin uyuşmazlık çıkması durumunda bu Devlete karşı davasını tahkim mahkemesinde açmasına imkân veren yatırımc1Devlet uyuşmazlık çözümü mekanizmasının uygulanmasını engellemeyeceği şeklinde yorumlanması gerektiğine karar vermesini önermektedir. ${ }^{120}$

\section{Slovakya Cumhuriyeti v. Achmea BV, ABAD Kararı}

ABAD'a Almanya Federal Adalet Mahkemesi tarafından ön karar verilmesi için gönderilen davada Slovakya Cumhuriyeti, IYYA'nın 8. maddesindeki tahkim şartının, ABİHA'nın 18, 267 ve 344. maddeleriyle uygunluğuna ilişkin tereddütlerini dile getirmiştir. Başvurucu mahkeme bu tereddütlere katılmamasına rağmen, Mahkeme'nin daha önce bu meseleler hakkında kararı bulunmamasını ve bu meselelerin Üye Devletler arasında yürürlükte bulunan çok sayıda anlaşmanın benzer tahkim şartlarını içermesi nedeniyle ciddi önem arz etmesini dikkate alarak, görmekte olduğu davada karar vermesi için ABAD'a bu başvuruyu yapma gereği hissetmiştir. ${ }^{121}$

Almanya Federal Adalet Mahkemesi yargılamaya ara verilmesine ve aşağıdaki soruların ön karar için $\mathrm{ABAD}$ 'a gönderilmesine karar vermiştir:

(1) ABİHA m. 344, AB Üye Devletleri arasında yapılan (AB-içi İYA olarak adlandırılmaktadır) yatırımların korunmasına ilişsin ikili anlaşmalarda yer alan, bir Âkit Devletin vatandaşının diğer Âkit Devletteki yatırımlarına

118 Wathelet, para. 264-266.

119 Wathelet, para. 272.

120 Wathelet, para. 273.

121 ABAD Achmea Kararı, para. 14. 
ilişkin uyuşmazlık çıkması durumunda, diğer Âkit Devlete karşı davasını tahkim mahkemesinde ileri sürebilmesine imkân tanıyan hükmün, yatırımların korunması anlaşmasının Âkit Devletlerden birinin AB'ye girmesinden önce akdedilmesi ancak uyuşmazlığın tahkime $\mathrm{AB}$ 'ye girdikten sonra götürülmesi durumunda uygulanmasinı engellemekte midir?

Eğer birinci soru olumsuz olarak cevaplanacaksa:

(2) ABİHA m. 267 böyle bir hükmün uygulanmasını engellemekte midir?

Eğer birinci ve ikinci soru olumsuz olarak cevaplanacaksa:

(3) ABİHA m. 18'in birinci fikrası 1. soruda tarif edilen durumda böyle bir hükmün uygulanmasını engellemekte midir? ${ }^{122}$

Hukuk Sözcüsü bu konuda yukarıda incelediğimiz görüşünü 19 Eylül 2017 tarihinde sunmuştur. Çek, Macar ve Leh Hükümetleri bu görüşe katılmadıklarını beyan etmişlerdir. ${ }^{123}$

ABAD başvurucu mahkemenin ilk iki sorusunu birlikte cevaplamıştır. ABAD, Üye Devletlerin paylaştığı ortak değerleri ve aralarında dürüst işbirliği ilkesine uymaları gerektiğini ve $A B$ hukukunun özerkliği ve niteliklerinin korunmasının, $\mathrm{AB}$ hukukunun insicamını ve yeknesak biçimde yorumlanmasının sağlanmasının milli mahkeme veya yargılama yetkisi olan makamların ve Adalet Divanı'nın görevi olduğunu belirtmiştir. ${ }^{124}$ Bunun gerçekleştirilmesi için, oluşturulan yargı sisteminde ABİHA 267. maddesinde düzenlenen, mahkemeler -özellikle Adalet Divanı ve Üye Devletlerin mahkeme veya yargılama yetkisi olan makamları- arasında diyaloğu sağlayan ön karar prosedürü sistemin temel taşı olarak yer aldığını ifade etmiştir. Ayrıca söz konusu yarg1 sisteminin, AB hukukunun yeknesak yorumlanmasinı güvenceye alma amacına sahip olduğu, böylece $\mathrm{AB}$ hukukunun tutarlılığına, tam etkinliğine, özerkliğine ve sonuç olarak Antlaşmalarla oluşturulan bu hukukun hususi mahiyetinin sağlanmasına hizmet ettiğini beyan etmiştir. ${ }^{125}$

ABAD, öncelikle Hollanda-Çekoslovakya IYYA m. 8'de belirtilen tahkim mahkemesinin, $\mathrm{AB}$ hukukunun yorumlanması veya uygulanmasıyla ilgili olan uyuşmazlıkların çözümüne bakma konusunda yetkili olup olmadığı hususuna

122 ABAD Achmea Kararı, para. 23.

123 ABAD Achmea Kararı, para. 24-25.

124 ABAD Achmea Kararı, para. 32-36.

125 ABAD Achmea Kararı, para. 37. 
Abad'ın Achmea Kararı ve Yatırımcı-Devlet Uyuşmazlık Çözümü Açisindan...

bakmıştır. IYA m. 8'de belirtilen tahkim mahkemesine AB hukukunu, özellikle iş kurma serbestisi ve sermayenin serbest dolaşımı dahil, temel özgürlüklere ilişkin hükümleri yorumlaması ve pek tabii uygulaması için başvurulabileceği görüşündedir. ${ }^{126}$ İkinci olarak, IYYA m. 8'deki gibi bir tahkim mahkemesinin (arbitral tribunal) AB yargı sistemi içinde yer alıp almadığı ve özellikle ABİHA m. 267 anlamında bir Üye Devletin mahkemesi veya yargilama yetkisi olan bir makam1 ${ }^{127}$ olarak değerlendirilip değerlendirilemeyeceğini irdelemiştir. Mahkeme, AB yargı sistemi içerisinde yer alan Üye Devletler tarafindan yargilama yetkisi olan bir mahkemenin kurulmasının sonucunun, bu makamın verdiği kararların $\mathrm{AB}$ kurallarının tam etkinliğini sağlayama yetkisi olan mekanizmaların denetimine tabi olması olduğunu ifade etmiştir. Hukuk Sözcüsü'nün de dayanak olarak gösterdiği Ascendi Beiras Litoral e Alta, Auto Estradas das Beiras Litoral e Alta davasında Mahkeme'nin, davada inceleme konusu olan makamın (mahkemenin) "Üye Devletin mahkeme veya yargılama yetkisi olan makamı" statüsünü söz konusu mahkemenin Portekiz Anayasası tarafından vergi uyuşmazlıklarının çözümünde yargı sisteminin bir parçası olması durumundan hareket ederek belirlediği ${ }^{128}$, İYA m. 8'de ifade edilen tahkim mahkemesinin ne Hollanda'nın ne de Slovakya'nın yargı sisteminin bir parçası olduğu, yetkisinin bu Üye Devletlerin mahkemeleri yanında istisnai mahiyette olduğu, tahkim mahkemesinin bu karakteristiğinin onun ABİHA m. 267 anlamında bir Üye Devletin mahkemesi veya yargılama yetkisi olan makamı olarak değerlendirilmesine engel olduğu kararına varmıştır. ${ }^{129} \mathrm{ABAD}$ önceki kararlarında üç Benelüks Devletince ortak olarak

126 ABAD Achmea Karar1, para. 39-42.

127 ABİHA m. 267'de geçen “courts or tribunals” tabiri Avrupa Birliği Başkanlığı'nın Türkçe çevirilerinde sadece mahkeme olarak geçmektedir. Farklı hukuk düzenlerini içerisinde barındıran AB, farklı düzenlemeleri dikkate alarak "tribunal" yani yargılama yetkisini Üye Devletlerin yasalarından alan makamlar, kurullar, mahkemelerin de bu madde de ifade edilen yetkileri kullanabileceğini düzenlemiştir. Hangi özelliklere sahip makamların, kurumların, mahkemelerin bu kapsama girdiği Mahkeme'nin kararlarında incelenmiştir. Bu kararlara göre ABIHA m. 267'de yer alan "Üye Devletin mahkeme veya yargılama yetkisi olan makamı" (any court or tribunal of a Member State) ifadesi kapsaminda bir yarg1 makamı addedilmesi için o makamın, kanun ile oluşturulup oluşturulmadı̆̆ına, daimî olup olmadığına, yetkisinin zorunlu olup olmadığına, usulünün inter partes olup olmadığına, hukuk kurallarını uygulayıp uygulamadığına, bağımsız olup olmadığına bakılmaktadır. Ayrıca bir davanın önünde görülüyor olması ve yaptığı yargılama üzerine yargısal mahiyette bir karar doğuracak şekilde hüküm vermesi için başvurulmuş olması gerekmektedir.

128 Judgment of the Court (Second Chamber), Case C-377/13, Ascendi Beiras Litoral e Alta, Auto Estradas das Beiras Litoral e Alta SA v. Autoridade Tributaria e Aduneira, ECLI:EU:C:2014:1754, 12 June 2014, para. 25, 26.

129 ABAD Achmea Kararı, para. 43-46. 
kurulan Benelüks Adalet Divanı gibi ortak mahkemelerin, herhangi bir Üye Devletin mahkemesi veya yargılama yetkisi olan makamı gibi Mahkeme'ye ön karar için başvurmasını engelleyen iyi bir sebep bulunmadığını ifade etmiştir. ${ }^{130}$ Ancak Mahkeme, Benelüks Mahkemesi'nin amacının üç Benelüks Devletinde ortak olan hukuk kurallarının yeknesak olarak uygulanmasını sağlamak ve ortak Benelüks hukuk kurallarının nihai yorumuna kılavuzluk eden milli mahkemelerde görülen yargılamaların bir aşaması olduğunu, söz konusu tahkim mahkemesinin ise Benelüks Adalet Divanı'nın aksine, birden fazla Üye Devlet tarafından kurulan bir ortak mahkeme olmadığını ve tahkim mahkemesi ile Üye Devletlerin yargı sistemleri arasında böyle bir ilişki bulunmadığını belirtmiştir. ${ }^{131} \mathrm{Bu}$ nedenlerle Mahkeme, tahkim mahkemesinin ABİHA m. 267 anlamında bir Üye Devletin mahkemesi veya yargılama yetkisi olan makamı olarak değerlendirilemeyeceği ve bu sebeple Mahkeme'ye ön karar için başvurma yetkisine sahip olmadığ kararına varmıştır. ${ }^{132}$

Kanaatimizce Mahkeme yukarıda yer verilen tespitlerini yanlış bir yoruma dayandırmıştır. Zira söz konusu IYYA kapsamında Hukuk Sözcüsü’nün de ileri sürdüğü gibi iki devletin anlaşmasıyla bir ortak mahkemenin kurulması söz konusudur. Öncelikle, Âkit Devletler uyuşmazlıkların dostane yolla çözülememesi durumunda yatırımcıların tahkim mahkemesine başvurmasına rızalarını beyan etmişlerdir. Hukuk Sözcüsü bu tahkim mahkemesinin daimîliği konusunu yukarıda incelediğimiz şekilde tartışmıştır ve bu konudaki görüşü Âkit Devletlerin iradeleri nazara alındığında ABAD'ın kanaatine kıyasla daha mantıklıdır. İkinci olarak, bu mahkemenin nasıl teşekkül edeceği, usulünün ne olacağı, hangi kuralları uygulayacağı açıkça düzenlenmiş ve bu tahkim mahkemesince verilecek kararların nihai ve tarafları bağlayıcı olduğu akdedilmiştir.

ABAD üçüncü olarak, IYYA m. 8'deki gibi bir tahkim mahkemesinden verilen hakem kararının, Avrupa Birliği Antlaşması m. 19 uyarınca, tahkim mahkemesinin çözmesi gereken $\mathrm{AB}$ hukuku meseleleri hakkında ön karar için Mahkeme'ye başvurmasını teminat altına alacak şekilde, bir Üye Devlet mahkemesinin incelemesine tabi olup olmadığını incelemiştir. Tahkim mahkemesi IYA m. 8/5'e göre, UNCITRAL tahkim kurallarını uygulayarak

\footnotetext{
130 Parfums Christian Dior karar1, C-337/95, EU:C:1997:517, para. 21; Judgment of the Court (Grand Chamber), Case C-196/09, Paul Miles and Others v. Écoles Européennes (European Schools), ECLI:EU:C:2011:388, 14 June 2011, para. 40.

131 ABAD Achmea Kararı, para. 47-48.

132 ABAD Achmea Kararı, para. 49.
} 
Abad'ın Achmea Kararı ve Yatırımcı-Devlet Uyuşmazlık Çözümü Açisindan...

kendi usul kurallarını belirleyecek ve tahkim yerini dolayısıyla önüne gelen uyuşmazlık hakkında verdiği kararın geçerliliğini denetleyecek yargısal denetim usulüne uygulanacak hukuku da kendisi seçmektedir. ${ }^{133}$ Tahkim mahkemesi Achmea'nın talebiyle tahkim yeri olarak Frankfurt'u belirlemiștir. Böylece bu hukuk Alman hukuku olmuştur. Yargısal denetim milli hukukunun izin verdiği ölçüde yapılabileceğinden Alman Hukuk Usulü Kanunu Paragraf 1059/2'ye göre tahkim anlaşmasının uygulanacak hukuka göre geçerliliği ve hakem kararının tanıma ve tenfizinin kamu düzenine aykırı olup olmadığıyla sınırlı bir denetim mümkündür. ${ }^{134}$ ABAD'ın ticari tahkime ilişkin önceki kararlarında, hakem kararlarının Üye Devlet mahkemelerince denetiminde AB hukukunun temel hükümlerinin incelenebilmesi için gerekirse Mahkeme'ye ön karar başvurusu yapılabileceğine hükmedilmiştir. ${ }^{135}$ Ancak ABAD, IYYA m. 8'deki gibi tahkim yargılamalarını ticari tahkim yargılamalarından farklı olarak değerlendirmiştir. Mahkeme'ye göre ticari tahkim yargılamaları tarafların özgür iradelerine dayanırken, IYYA m. 8'deki gibi tahkim yargılamaları Üye Devletlerin kendi mahkemelerinin yetkisini kaldırdıkları bir anlaşmadan kaynaklanmaktadir. ${ }^{136}$

Kanaatimizce burada Mahkeme'nin gözden kaçırdığı husus IYYA m. 8'deki uyuşmazlığın tahkim mahkemesine götürülmesinin de tarafların özgür iradelerine dayanmakta olduğudur. Âkit Devletler buna önceden rıza göstermiştir, yatırımcılar da uyuşmazlıklarını milletlerarası tahkime götürerek bu konudaki özgür iradelerini ortaya koymuşlardır. Mahkeme'ye göre bu uyuşmazlıklarda $\mathrm{AB}$ hukukunun uygulanmasını veya yorumlanmasını ilgilendirebilecek durumlar ortaya çıktığında hakem kararlarının Üye Devlet mahkemelerince denetimi sırasında $\mathrm{AB}$ hukukunun temel hükümlerinin incelenebilmesi için Mahkeme'ye ön karar başvurusu yapılamayacaktır. ${ }^{137}$ ABAD, ifade ettiği görüşleri dolayısıyla IYYA m. 8'de öngörülen tahkim mahkemesinin karakteristiğini de dikkate alarak, bu mahkemeler önüne gelen uyuşmazlıklarda $\mathrm{AB}$ hukukunun yorumlanması veya uygulanması

\footnotetext{
133 ABAD Achmea Kararı, para. 51.

134 ABAD Achmea Karar1, para. 52-54.

135 Judgment of the Court, Case C-126/97, Eco Swiss China Time Ltd v. Benetton International NV, ECLI:EU:C:1999:269, 1 June 1999, para. 35, 36, 40. Judgment of the Court (First Chamber), Case C-168/05, Elisa María Mostaza Claro v. Centro Móvil Milenium SL, ECLI:EU:C:2006:675, 26 October 2006, para. 34-39.

136 ABAD Achmea Kararı, para. 55.

137 ABAD Achmea Kararı, para. 55.
} 
durumunda $\mathrm{AB}$ hukukunun tam etkinliğini sağlayacak şekilde çözümlenmesini engelleyebilecek durumların çıkması ihtimali olduğunu belirtmiştir. ${ }^{138}$ Mahkeme, IYYA m. 8'de öngörülen tahkim mahkemesinin yetki alanına giren uyuşmazlıkların hem İYA'nın hem de AB hukukunun yorumlanmasıyla ilgili olabileceğini ve bu uyuşmazlıkların $\mathrm{AB}$ yargı sistemi içinde olmayan bir mahkemeye götürülmesi imkânının Avrupa Birliği tarafından akdedilen bir anlaşma ile değil de Üye Devletler tarafından akdedilen bir anlaşma ile sağlanmasını, hem Üye Devletler arasındaki ortak güven ilkesine hem de Antlaşmalarla oluşturulan hukukun ABİHA m. 267'de öngörülen ön karar prosedürüyle teminat altına alınan hususi mahiyetinin korunmasına zarar verebileceğini dile getirerek, IYYA m. 8'in Üye Devletler arasında dürüst iş birliği ilkesine aykırı olduğuna ve $\mathrm{AB}$ hukukunun özerkliğine olumsuz etki edeceğine karar vermiştir. ${ }^{139}$

Bu noktada IYYA m. 8'e göre kurulmuş olan bir tahkim mahkemesinin verdiği kararın ön karar prosedürü yoluyla Mahkeme'nin önüne geldiği unutulmamalıdır. Bizce Mahkeme burada fazla endişeli davranarak faturayı Üye Devletler arasında akdedilen IYYA'lar kapsamında oluşturulan bütün tahkim mahkemelerine kesmiştir. Aslında Mahkeme yorumunu yaparken AB hukukunun özerkliğine ve yeknesak biçimde uygulanmasına zarar vererek ön karar prosedürüne imkân tanımayan tahkim mahkemesi kararlarının AB kamu düzenine aykırı olduğu yönünde bir karar vererek, buna imkân verenleri AB Antlaşmalarına uygun addetseydi vermiş olduğu kararın doğurabileceği pek çok olumsuz sonucun önüne geçmiş olacaktı. AB-içi IYA'lar yürürlükten kaldırılmış olsa dahi bu IYYA'larda yer alan gün batımı hükümleri (sunset clause) çerçevesinde, örneğin Hollanda-Çekoslovakya IYYA ${ }^{140} \mathrm{~m} .8$ kapsamında oluşturulacak bir tahkim mahkemesinin tahkim yeri olarak AB Üye Devletleri dışında bir ülkede olması ve verilecek kararın da AB Üye Devletleri dışında bir ülkede tanıma ve tenfizinin talep edilmesi durumunda ABAD'ın çekindiği bu durum meydana gelebilecekti. Bu nedenle AB Üye Devletleri Arasındaki İkili Yatırım Anlaşmalarının Feshi Anlaşması'nda gün batımı hükümlerinin kaldırılmasına ilişkin düzenlemeler m. $2 / 2$, 3 ve $4 / 2$ 'de yer almaktadır. ${ }^{141}$

138 ABAD Achmea Karar1, para. 56.

139 ABAD Achmea Kararı, para. 57-59.

140 Hollanda-Çekoslovakya İYA m. 13/3 kapsamında İYA’nın sona ermesinden önce yapılan yatırımlar için IYYA'nın sona ermesinden itibaren 15 yıl boyunca hükümlerinin geçerli olmaya devam edeceği düzenlenmektedir.

141 AB Üye Devletleri Arasındaki İkili Yatırım Anlaşmalarının Feshi Anlaşması akdedilmeden 
Abad'ın Achmea Kararı ve Yatırımcı-Devlet Uyuşmazlık Çözümü Açisindan...

Ancak Fesih Anlaşması'nı imzalamayan dört AB Üye Devletinin mevcut olduğu ve Fesih Anlaşması'nın henüz bütün taraf devletlerde yürürlüğe girmediği unutulmamalıdır. Ayrıca bu noktada, feshedilen anlaşmalara taraf olan devletlerin ortak rızası olsa dahi anlaşmalarda yatırımcılara verilen güvencelere haklı beklenti ile itimat ederek uzun dönemli yatırım yapan yatırımcıların haklarının korunması gerektiği görüşüne katılmaktayız. Bunun sebebi, IYYA'lar devletler arasında yapılmasına rağmen anlaşmaların akdedilmesiyle birlikte anlaşmalarda sağlanan hak ve güvencelerin artık devletlere değil âkit devletlere tabii olan yatırımcılara ait olmasıdır. Âkit devletlerin anlaşarak anlaşmayı sona erdirmeleri durumunda dahi yatırımcılar bu anlaşmalarla kazandıkları hak ve güvenceleri gün batımı hükmü süresi boyunca ileri sürmeye devam edebilecektir. Gün batımı hükümlerinin esas amacı yatırımcıların haklarını yatırımların korunması ve teşviki anlaşmaları sona erdirilse bile belirli bir süre daha devam ettirerek korumaktır. ${ }^{142}$

ABAD yaptığ 1 bu değerlendirmeler sonucunda, ABİHA m. 267 ve 344'ün Üye Devletler arasında akdedilen uluslararası bir anlaşmada yer alan ve Üye Devletlerden birinin tabiiyetinde bulunan bir yatırımcının diğer Üye Devletteki yatırımına ilişkin uyuşmazlık çıkması durumunda, yatırımının bulunduğu Üye Devlete karşı, o Üye Devletin yetkisini kabul etme taahhüdünde bulunmuş olduğu bir tahkim mahkemesine dava açabilmesini sağlayan Hollanda Krallığg ile Çek ve Slovak Federatif Cumhuriyeti Arasında Yatırımların Karşılıklı Teşviki ve Korunması Anlaşması m. 8 gibi bir hükmü engeller nitelikte olduğu şeklinde yorumlanması gerektiği kararına varmıştır. ${ }^{143}$

önce, Almanya, Avusturya, Finlandiya, Fransa ve Hollanda'nın AB-içi yatırım anlașmalar1 konusunda yayımladıkları resmi olmayan bilgi yazısında (non-paper) bu ülkelerin delegasyonlarının bu anlaşmalardaki ve daha önce sona erdirilmiş ancak gün batımı hükümleri devam eden $\mathrm{AB}$-içi yatırım anlaşmalarındaki gün batımı hükümlerinin uygulanamayacak şekilde bütün hükümlerinin kaldırılmasına hazırlıklarını yapması gerektiği belirtilmiştir. Council of the European Union Trade Policy Committee (Services and Investment), IntraEU Investment Treaties Non-paper from Austria, Finland, France, Germany and the Netherlands, 7 April 2016.

142 Guled Yusuf, Godwin Tan, Case Comment United Utilities (Tallinn) BV v Estonia, "ICSID Arbitration after Achmea: the Beginning of the End or the End of the Beginning?", 2020, 35(1-2), ICSID Review - Foreign Investment Law Journal, s. 13; Magyar Farming Company Ltd, Kintyre Kft and Inicia Zrt v. Hungary, ICSID Case No. ARB/17/27, Award, para. 223224. EŞA'da yer alan gün batımı hükümleri için bkz. Peter Cameron, International Energy Investment Law: The Pursuit of Stability, Oxford University Press, New York, 2010, s. 162 164.

143 ABAD Achmea Kararı, para 60. 


\section{SONUÇ}

AB'nin politikalarında son yıllarda meydana gelen değişiminin yatırım hukukuna ve dolayısıyla yatırımcı-devlet uyuşmazlıklarının çözümüne yansımasını ABAD'ın güncel kararlarında açıkça görmekteyiz. Yaşanan bu değişimin en güzel özetini, Achmea davasındaki ön karar başvurusu için hazırladığ1 görüşünde Hukuk Sözcüsü Wathelet, Avrupa Komisyonu'nun ve AB kurumlarının yıllar boyunca İYA'ları Orta ve Doğu Avrupalı aday ülkelerin $\mathrm{AB}$ ile katılım müzakerelerinde neden katılıma hazırlık için imzalamaları gerekli görülen unsurlar arasında saydığını ve bu İYA'ların sadece katılım sürecinde geçerli olması düşüncesine sahip idiyseler neden katılım anlaşmalarının bu İYA'ların sona ermesine ilişkin hüküm içermediği ve neden bu anlaşmaların bazılarının 30 yıldan fazla süredir devam etmekte olduğunu sorarak, $\mathrm{AB}$ politikalarının tam aksi yöne nasıl evrildiğini gözler önüne sermektedir.

Wathelet ayrica, Avrupa Komisyonu'nun ve AB kurumlarının mevcut pozisyonlarını savunurken zor durumda kaldıklarını da müşahede etmektedir. Komisyon'un yazılı görüşünde yatırımcılar ile Üye Devletler arasındaki uyuşmazlıklarda yatırımcının aslında kendi hakkını kullanmadığını ancak tabiiyetinde olduğu devlete IYYA'nın verdiği bir hakkı kullandığını iddia etmesini, Hukuk Sözcüsü, Komisyon'un atıf yaptığı tahkim davalarıyla çelişmesi, genelgeçer bir kabule sahip olmaması, uluslararası anlaşmaların belirli koşullarla kişilere haklar vermesi ve IY A'ların da açıkça yatırımcılardan bahsederek doğrudan onlara haklar vermesine dayanarak eleştirmektedir. ${ }^{144}$ Hukuk Sözcüsü Komisyon'un argümanlarının geçersizliğini ve çelişkilerini yatırım hukukuna dair temel kitaplara atıf yaparak yüzlerine vurmaktadır. ${ }^{145}$ Burada gerçekten de Komisyon'un Brüksel'in politikalarının değişimini gerekçelendirirken akla karayı seçtiğini görülmektedir.

Achmea kararından çıkan yansımalara bakacak olursak, bunların belki de en önemlisi yatırım uyuşmazlıklarının çözümü amacıyla AB-içi IYA'lara dayanarak kurulan tahkim mahkemelerinde verilen kararların AB Üye Devletlerinde uygulama kabiliyetlerini yitirmesidir. Gaillard bu kararı bir anda 200 AB-içi yatırım anlaşmasını patlatan ve tam olarak nereye varacağı henüz kestirilemeyen bir dizi kaotik yansımayı başlatan bir bombaya

\footnotetext{
144 Wathelet, para. 154-159.

145 Wathelet, para. 155-156.
} 
Abad'ın Achmea Kararı ve Yatırımcı-Devlet Uyuşmazlık Çözümü Açisindan...

benzetmektedir. ${ }^{146} \mathrm{Bu}$ bomba ile $\mathrm{ABAD}, \mathrm{AB}$ Üye Devletlerinin taraf olduğu ve $A B$ hukukunun uygulanacağ Anlaşması ile kurulan tahkim mahkemelerinin önünü kesmektedir. ${ }^{147} \mathrm{Bu}$ durum AB Üye Devletleriyle ikili yatırım anlaşması akdetmiş olan diğer devletlerin yatırımcılarının ilgili anlaşmalarda öngörülen uyuşmazlık çözüm yöntemlerinden devlet mahkemelerine gidilmesi dışında kalan tahkim mahkemelerinin seçilmesini engellemektedir. Achmea kararı sonrasında ABiçi yatırım uyuşmazlıklarının çözümü için en olası yol Üye Devletlerin, kararda da bahsi geçen Benelüks Adalet Divanı örneğinde olduğu gibi, daimî ortak bir yatırım mahkemesi kurması olarak gözükmektedir. ${ }^{148}$ Yakın zamanlarda AB tarafından bu siyasi taktik, özellikle ticaret, yatırım ve çevre konularında sıkça kullanılmaya başlanması, üzerine düşünülmesi gereken bir mesele olarak $\mathrm{AB}$ Üye Devletleri dahil bütün devletlerce dikkate alınmalıdır. Avrupa Birliği hukuki kararların arkasına sığınarak elindeki yaptırım sopasıyla diğer ülkelere "talep ettiğim istikamette hareket etmemeniz hâlinde aramızdaki ticaret, mal ve hizmet satımı ve yatırımlar etkilenir" şantajında bulunmaktadır. ${ }^{149} \mathrm{AB}$

146 Gaillard, s. 555.

147 Achmea ve Komstroy kararları birlikte değerlendirildiğinde Avrupa Birliği, UNCITRAL Çalışma Grubu III'te ve EŞA'nın güncellenmesi için yapılan çalışmalarda mevcut sistemin geliştirilmesi gibi imkânlar üzerine yoğunlaşılmasını değil de kendi görüşü yönünde daimî bir yatırım mahkemesinin kurulması üzerine odaklanılmasını sağlamaya çalıştığı görülmektedir. AB bunun siyasi yönünü takip ederken, ABAD hukuki altyapısını hazırlamaktadır.

Bu anlamda Karacan'ın Achmea ve 1/17 Sayılı Mahkeme Görüşü birlikte değerlendirerek yatırımcı-devlet tahkiminde sona yaklaşıldığı ve çok taraflı bir yatırım mahkemesine doğru sürecin evrildiği kanaatine, AB'nin ABAD’1 da yanına alarak oluşturduğu durumun göstergesi olması açısından katılmaktayız. Bkz. Pınar Karacan, "Avrupa Birliğinde "Achmea” Kararı ve "1/17 Sayılı Görüş" Işı̆̆ında "Yatırımcı-Devlet” Uyuşmazlık Çözüm Mekanizmasının Geleceği”, 2020, 40(2), Public and Private International Law Bulletin, Prof. Dr. Cemal Şanlı'ya Armağan, s. 1532-1533. Opinion 1/17 of the Court (Full Court) Opinion pursuant to Article 218(11) TFEU, ECLI:EU:C:2019:341, 30 April 2019 (1/17 Sayılı Mahkeme Görüşü)

148 Avrupa Birliği'nin UNCITRAL Çalışma Grubu III'ün yürüttüğü yatırımcı-devlet uyuşmazlık çözümünde olası reformlar hakkında gönderdiği görüşünde daimî, birinci derece mahkemesi ve temyiz mahkemesinden oluşan iki aşamalı, tam zamanlı hâkimlerin görev yaptığ bir sistemle var olan sorunların giderilebileceğinden bahsetmektedir. Buradan hareketle ABiçi yatırım uyuşmazlıklarının çözümünde de benzer bir yöntemi uygulamaya geçirmeleri kuvvetle muhtemeldir. AB ve Üye Devletleri'nin UNCITRAL Çalışma Grubu III'ün yürüttüğü yatırımc1-devlet uyuşmazlık çözümünde olası reformlar hakkında gönderdiği görüşü için bkz. United Nations Commission on International Trade Law, Submission from the European Union and its Member States, Working Group III (Investor-State Dispute Settlement Reform) Thirty-seventh Session New York, 1-5 April 2019, A/CN.9/WG.III/WP.159/ Add.1, 24 January 2019.

149 Avrupa Birliğinin bu tutumuna rağmen Micula kararını, Komisyon ve Romanya'nın itirazlarına rağmen, ABD ve İngiltere'nin tenfiz ettiğini görmekteyiz. Ayrıntılı bilgi için bkz. 
ayrıca kendi Üye Devletlerine karşı da, ABİHA m. 206 ve m. 207'de yer alan yatırıma ilişkin yetkisini de arkasına alarak, bu devletleri daha önce katılım sürecinde ikili yatırım anlaşması yapmaya zorlamış olabileceğini ancak artık politikasını değiștirdiğini, Üye Devletlerin bu alanda aralarında istedikleri gibi anlaşma yapamayacaklarını ve AB'nin yeni yaklaşımını benimsemek zorunda olduklarını dayatmaktadır.

Achmea kararının diğger bir yansıması ise, uluslararası yatırım hukukunda yatırımcının bir ülkeye yatırımını yaparken dikkat ettiği unsurların en önemlilerinden olan hukuki istikrarın ve öngörülebilirliğin verilen bu kararla derinden zedelenmesidir. ABAD, AB Üye Devletlerinin ikili yatırım anlaşmalarında karşılıklı olarak vermiş oldukları yatırım uyuşmazlıklarının tahkim yoluyla çözülmesine imkân veren tahhütleri ortadan kaldırmıştır. AB Üye Devletleri ikna ederek Üye Devletler arasında yapılan ikili yatırım anlaşmalarını ortadan kaldırılmasını sağlamış olsa dahi, bu anlaşmaların yürürlükte bulunduğu süreçte buna güvenerek yatırımlarını gerçekleştiren yatırımcıların menfaatlerini ciddi ölçüde zedelemiştir. Bu durum AB'de yeni yatırım yapmayı planlayan yatırımcıları önlerindeki hukuki imkânları tekrar düşünmeye ve yatırımcının korunmasına ilişkin mevcut mevzuatı yeniden değerlendirmeye sevk edecektir. Yatırımcılar şirket yapılarını tekrar gözden

Ioan Micula, Viorel Micula and others v. Romania (I), ICSID Case No. ARB/05/20; Judgment of the Supreme Court of the United Kingdom [2020] UKSC 5 - 19 Feb 2020, para. 117-118, <https://jusmundi.com/en/document/decision/en-ioan-micula-viorel-micula-andothers-v-romania-i-judgment-by-the-supreme-court-of-the-united-kingdom-wednesday19th-february-2020\#decision 6827> Erișim Tarihi 15.11.2021; Memorandum Opinion and Order of the United States District Court for the District of Columbia - 20 Nov 2020, para. $25,<\mathrm{https}$ ://jusmundi.com/en/document/decision/en-ioan-micula-viorel-micula-andothers-v-romania-i-memorandum-opinion-and-order-of-the-united-states-district-courtfor-the-district-of-columbia-friday-20th-november-2020\#decision_14093> Erişim Tarihi 15.11.2021; Memorandum Opinion and Judgment of the United States District Court for the District of Columbia - 8 Nov 2021, para. 17-19, <https:/jusmundi.com/en/document/ decision/en-ioan-micula-viorel-micula-and-others-v-romania-i-memorandum-opinionand-judgment-of-the-united-states-district-court-for-the-district-of-columbia-monday-8thnovember-2021\#decision_18208> Erişim Tarihi 15.11.2021.

Komisyon ABD'de görülen ICSID yatırım tahkimi kararının tenfizine ilișkin olan Micula davası'na, EŞA'ya dayanarak verilen yatırım tahkimi kararının tenfizine ilişkin olan Masdar Solar \& Wind Cooperatief U.A. davas1, Foresight Luxembourg Solar davası ve Eiser Infrastructure Limited and Energia Solar Luxembourg S.A.R.L davasına, ICSID'de görülen EŞA'ya dayanarak verilen yatırım tahkimi kararının iptaline ilișkin olan EISER v. Spain davasına gözlemlerini iletmiştir. Komisyon'un diğer mahkemelere ilettiği görüşleri için bkz. Observations Provided by the Commission to Other Courts, $<$ https://ec.europa.eu/ competition-policy/state-aid/national-courts/observations-other-courts_en> Erişim Tarihi 15.11.2021. 
Abad'ın Achmea Kararı ve Yatırımcı-Devlet Uyuşmazlık Çözümü Açisindan...

geçirmek durumunda kalabilecektir. Örneğin AB'de yatırım yapmadan önce yatırımını yapacağı Üye Devlet ile arasındaki ikili yatırım anlaşmasında milletlerarası tahkime gitme imkânı sağlayan hüküm bulunan üçüncü bir ülkeye yatırımını götürüp burada kuracağı başka bir şirket üzerinden yatırımını AB Üye Devletine yapmak gibi yöntemlere başvurabilecektir. ${ }^{150}$ $\mathrm{Bu}$ kararların yatırımciların AB'ye olan güvenini azaltabileceği hususu Litvanya'nın Fesih Anlaşması'na ilişkin deklarasyonunda, “AB-içi IYA'ların feshi ile yatırımcıların ihlal edilen hakların milletlerarası tahkimde savunma ihtimallerinin ellerinden alınması, yatırımcı haklarının korunmasina ve AB'deki yatırım ortamına olumsuz etki edebilecektir" şeklinde ifade edilmektedir. ${ }^{151}$ AB Üye Devletlerinde uluslararası yatırım uyuşmazlıklarının çözümü için devlet mahkemelerine alternatif olarak, tarafsız ve bağımsız karar vereceği düşünülen tahkim mahkemelerine gitme imkânı kısıtlanan yatırımcıların, bu gelişmelerden sonra, daha öngörülebilir ve uygun bir tahkim ortamına kavuşmak amacıyla ikili yatırım anlaşmalarında imkân bulunması durumunda tahkim yeri olarak AB Üye Devletleri yerine İngiltere, İsviçre ve Türkiye gibi ülkeleri seçmeye ve verilen kararları $\mathrm{AB}$ dışında tenfiz etmeye yönelme ihtimali bulunmaktadır.

Achmea kararının yansımalarından bir diğeri de 2 Eylül 2021 tarihinde ABAD’ın verdiği Komstroy kararıdır. Bu karar ile Enerji Şartı Anlaşması'na göre oluşturulan tahkim heyetlerinin $\mathrm{AB}$ Antlaşmalarıyla uyumsuz olduğunun hukuki dayanağı ortaya çıkmıştır. Hukuk Sözcüsü Wathelet, Üye Devletler ve $\mathrm{AB}$ tarafından ayrı ayrı imzalanan bütün tarafların eşit olduğu ve yatırımların korunmasına ve yatırımcı-devlet uyuşmazlık çözümüne dair maddi hukuk hükümleri içeren milletlerarası bir anlaşma olan Enerji Şartı Anlaşması'nın AB Antlaşmaları ve ABİHA'ya uyumluluğuna ilişkin hiçbir Üye Devletin ABAD'dan görüş istememiş olmasını bu anlaşmaların $\mathrm{AB}$ hukukuyla uyumsuz olabileceğine ilişkin en ufak bir şüpheleri bile olmamasına bağlamıştır. ${ }^{152}$ Hukuk Sözcüsü'nün bu görüşü ABAD'ın EŞA konusunu

150 Frédéric Gillion, Leonardo Carpentieri, "Construction Arbitration and BITs: Is There Still a Future for Intra-EU Investment Arbitration?”, 2018, Part 2, The International Construction Law Review, s. 179-180.

151 Declaration of Lithuania, Agreement for the Termination of Bilateral Investment Treaties Between the Member States of the European Union, <https://www.consilium.europa.eu/en/ documents-publications/treaties-agreements/agreement/?id=2019049\&DocLanguage $=$ en $>$ Erişim Tarihi 15.11.2021.

152 Hatta EŞA'nın hazırlanmasında AB'nin rolü göz önüne alındığında sanki bir AB dıș anlaşmasina benzetilmektedir. Ivana Damjanovic, Ottavio Quirico, "Intra-EU Investment Dispute Settlement under the Energy Charter Treaty in Light of Achmea and Vattenfall: A Matter 
fark etmesine yol açmış olsa gerek ki verdiği Komstroy kararında pek çok noktada Achmea kararına atıf yapıldığ 1 görülmektedir. ${ }^{153} \mathrm{Bu}$ kararda ABAD, EŞA m. 26/2-c'deki uyuşmazlık çözümü mekanizmasının bir Üye Devlet ile başka bir Üye Devletin tabiiyetinde olan yatırımcı arasındaki yatırıma ilişkin uyuşmazlıklara uygulanamayacağına hükmetmiştir. ${ }^{154}$ ABAD bu kararını da Achmea kararına benzer şekilde $A B$ hukukunun özerkliğinin ve hususi mahiyetinin korunmasına dayandırmıştır. ${ }^{155}$ Enerji Şartı Anlaşması'na dayanan ve aslında EŞA'nın uyuşmazlık çözümüne ilişkin hükümlerine ilişkin olmayan bir ön karar başvurusunda, tarafları AB'nin dışında olan (Moldova ve Ukrayna) ancak tahkim yerinin Fransa olarak seçildiği bir tahkim davasının söz konusu olduğu bir uyuşmazlıktaki meseleleri incelerken ABAD'ın bu kararı vermesi kanaatimizce Achmea'nın EŞA'ya etkisine ilişkin soruların bir an evvel açıklığa kavuşturulması isteği olması muhtemeldir.

Wathelet' in görüşüne benzer şekilde bir yorumlama ile mevcut yatırımc1devlet uyuşmazlık çözümü mekanizması ile yola devam edilebilecek iken, Brüksel çizgisinden yürüyen $A B A D$ 'ın desteğiyle $A B$, uluslararası yatırım hukukunda gerçekleştirmek istediği siyasi emellerine hukuki boyut vermektedir. Komisyon'un siyasi pozisyonunu $\mathrm{AB}$ adına amicus curiae olarak sunduğu belgelerden de anlamaktayız. Örneğin, ABD Güney New York Bölgesi Bölge Mahkemesi'ne Foresight Luxembourg Solar 1 S.A.R.L. ve diğerleri v. İspanya davası için sunduğu belgede AB'nin Achmea kararı neticesinde EŞA kapsamında görülen $\mathrm{AB}$-içi yatırım tahkiminin $\mathrm{AB}$ hukuku ile tamamen uyumsuz olduğu görüşünde olduğunu daha tartışmalar devam ederken Komstroy kararından yaklaşık on altı ay önce belirtmiştir. ${ }^{156}$ Avrupa Birliği'nin ve Euratom'un EŞA'ya Âkit Taraflar olmaları ve bu anlaşmayı akdederken yatırım uyuşmazlıklarının milletlerarası tahkim yoluyla çözümlenmesine karşı bir beyanlarının bulunmaması gözetildiğinde, $\mathrm{AB}$ 'nin taraf olmadığı bir IYYA kapsamında oluşturulan tahkim mahkemelerinin $\mathrm{AB}$ hukukuna uyumsuz

of Priority", Fall 2019, 26 (1), Columbia Journal of European Law, s. 115.

153 Komstroy karar1, para. 33, 42, 43, 45, 46, 51, 52, 53, 58, 59, 60, 61, 63 ve 64.

154 Komstroy karar1, para. 66.

155 Komstroy karar1, para. 63, 65.

156 Brief of The European Commission on Behalf of The European Union as Amicus Curiae in Support of The Kingdom of Spain, United States District Court for The Southern District of New York, Foresight Luxembourg Solar 1 S.A.R.L. et. al. v. The Kingdom of Spain, 3 May 2019, s. 23-24, <https://ec.europa.eu/competition-policy/system/files/2021-04/foresight_amicus_curiae_2019_US_district_court_newyork_observation_en.pdf $>$ Erişim Tarihi 15.11.2021. 
Abad'ın Achmea Kararı ve Yatırımcı-Devlet Uyuşmazlık Çözümü Açisindan...

olduğu sonucuna varılan Achmea kararını emsal göstermeleri, çok önceden Avrupa Birliğgi'nin bu görüşte olduğunu ve ABAD'ın görüşlerini etkilediğinin bir işaretidir.

Ayrıca, Hukuk Sözcüsü'nün de işaret ettiği gibi AB'nin yatırım tahkimi yargılamalarında $\mathrm{AB}$ hukukunun özerkliğinin korunması ve $\mathrm{AB}$ hukukunun yeknesak olarak yorumlanması ve uygulanması konusunda sahip olduğu sert görüşe rağmen, 2018'in Ekim ayında imzalanan AB-Singapur Serbest Ticaret Anlaşması - Yatırım Koruma Anlaşması'nda, Üye Devlet mahkemelerinin hakem kararlarının $\mathrm{AB}$ hukukuna uyumunu inceleyebileceği herhangi bir hukuki yöntem bulunmayan ICSID'i tahkim kurumu olarak seçilmesine anlam vermek zordur. ${ }^{157}$

Her ne kadar milletlerarası ticari tahkim hakkında $\mathrm{AB}$ 'nin görüşü $\mathrm{AB}$ Antlaşmaları'na uyumlu olduğu şeklinde olsa da, ABAD tarafından kabul edilen Achmea kararı neticesinde, yargılama sırasında Komisyon'un ve bazı $\mathrm{AB}$ üyesi devletlerin ileri sürdüğü, tahkim mahkemelerinin $\mathrm{AB}$ Antlaşmalarınca belirlenen yetki dağılımına ve $\mathrm{AB}$ hukuk sisteminin özerkliğine zarar verdiği gibi iddialar, $\mathrm{AB}$ hukukuna ilişkin meselelerin ortaya çıkma ihtimali bulunan bütün tahkim yargılamalarında gelecekte karşımıza çıkabilecektir. Achmea kararından, bu kararın milletlerarası ticari tahkime teşmil edilmeyeceğinin anlaşılmasına rağmen, ticari tahkimde de hakemler tarafından $\mathrm{AB}$ hukukunun yorumlanması ve uygulanması gerçekleştirilmektedir. ${ }^{158}$ İleride AB'nin "sistemsel risk" görüp, $\mathrm{AB}$ Üye Devletlerine tabii olanların taraf olduğu milletlerarası ticari tahkim davalarında, tahkim yerinin AB Üye Devletleri dışında seçilmesini, burada verilen kararların da AB hukukunun yeknesak yorumlanmasını ve $\mathrm{AB}$ hukuk sisteminin etkinliği ve özerkliğinin denetimini güvence altına almak için $\mathrm{AB}$ Antlaşmalarına aykırı olduğunu savunması önünde hiçbir engel kalmamıştır. Bunun sonucunda alternatif uyuşmazlık çözüm yollarından olan tahkime ve dolayısıyla Achmea kararına göre ABAD'ın

157 Gerçekten de ICSID Konvansiyonu m. 54/1'e göre Konvansiyon'a taraf devletlerin mahkemeleri ICSID tahkim kararlarını bağlayıcı olarak kabul etmek ve maddi yükümlülüklere dair hükümleri kendi ülkesinin mahkemelerinde verilmiş olan nihai karar gibi uygulamak zorundadır. Bu hakem kararını kamu düzeni yönünden inceleme imkânı bulunmamaktadır. Denetim imkânı olmaması dolayısıyla ABİHA m. 267'nin ihlali ihtimali ortaya çıkabilecektir. Thomas Hoppe, "The German Federal Court of Justice Marks a Possible Way for the CJEU's Preliminary Ruling: The Compatibility of Investment Arbitration Clauses in IntraEU Bilateral Investment Treaties with European Union Law", 2016, 59, German Yearbook of International Law, s. 623.

158 Gaillard, s. 556. 
denetiminde olmayan kararların AB Üye Devletlerinde icra edilebileceğine olan güven baltalanmıştır.

Son olarak, ABAD'ın verdiği bu kararlara rağmen, 2020 yılına gelindiğinde açılan 68 anlaşmaya dayanan yatırımcı-devlet tahkimi davasından 9'unun AB-içi uyuşmazlıklar olduğu ve bunların 5'inin AB-içi IYYA'lara, 4'ünün ise Enerji Şartı Anlaşmasına dayandığ 1 görülmektedir. Yatırımcılar, AB-içi yatırımcı-devlet uyuşmazlıklarını Achmea kararı ve AB Üye Devletleri Arasındaki İkili Yatırım Anlaşmalarının Feshi Anlaşması'na rağmen tahkime götürmeye devam etmektedir. Bu durum, AB'nin bütün engellemelerine ve mevcut yatırım tahkimi mekanizmasının eksik yönlerine rağmen yatırımcının devlete karşı korunmasında en iyi yöntemin halen milletlerarası tahkim olduğunu gösteren önemli bir istatistiktir.

\section{KAYNAKÇA}

2013/336/EU: Council Decision of 25 June 2013 Increasing the Number of Advocates-General of the Court of Justice of the European Union, OJ L 179, 29.6.2013.

Agreement for the Termination of Bilateral Investment Treaties Between the Member States of the European Union, SN/4656/2019/INIT, OJ L 169, 29.5.2020.

Aktoprak P, "Lizbon Antlaşması Sonrası Avrupa Birliği Adalet Divanı Bakımından Temel Hakların İncelenmesi”, 2017, 19(Özel Say1), DEÜ Hukuk Fakültesi Dergisi, Prof. Dr. Şeref Ertaş'a Armağan, s. 3025-3057.

Alyanak S, “Avrupa Birliği Adalet Divanı'nın Teşkilatlanması”, 2014, 72(3), Ankara Barosu Dergisi, s. 253-281.

Arsava F, Roma Antlaşmasında Ön Karar Prosedürü ve Bu Prosedür Çerçevesinde Doğan Sorunlar, Ankara Üniversitesi Avrupa Topluluğu Araştırma ve Uygulama Merkezi Araştırma Dizisi No: 31, Ankara, 2009.

Baykal S, Göçmen İ, Avrupa Birliği Kurumsal Hukuku, 1. Bask1, Seçkin Yayıncilık, Ankara, 2016.

Brief of The European Commission on Behalf of The European Union as 
Abad'ın Achmea Kararı ve Yatırımcı-Devlet Uyuşmazlık Çözümü Açisindan...

Amicus Curiae in Support of The Kingdom of Spain, United States District Court for The Southern District of New York, Foresight Luxembourg Solar 1 S.A.R.L. et. al. v. The Kingdom of Spain, 3 May 2019.

Cameron P, International Energy Investment Law: The Pursuit of Stability, Oxford University Press, New York, 2010.

Charter of Fundamental Rights of the European Union, OJ C 326, 26.10.2012.

Consolidated versions of the Treaty on European Union and the Treaty on the Functioning of the European Union Consolidated version of the Treaty on European Union Consolidated version of the Treaty on the Functioning of the European Union Protocols Annexes to the Treaty on the Functioning of the European Union Declarations annexed to the Final Act of the Intergovernmental Conference which adopted the Treaty of Lisbon, signed on 13 December 2007 Tables of equivalences, OJ C 202, 7.6.2016.

Council of the European Union Trade Policy Committee (Services and Investment), Intra-EU Investment Treaties Non-paper from Austria, Finland, France, Germany and the Netherlands, 7 April 2016.

Damjanovic I, Quirico O, "Intra-EU Investment Dispute Settlement under the Energy Charter Treaty in Light of Achmea and Vattenfall: A Matter of Priority", Fall 2019, 26 (1), Columbia Journal of European Law, s. 102156.

Declaration of the Representatives of the Governments of the Member States on the Legal Consequences of the Judgement of the Court of Justice in Achmea and on Investment Protection in the European Union, 15 January 2019.

Gaillard E, "The Myth of Harmony in International Arbitration", 2019, 34(3), 2018 Lalive Lecture, ICSID Review, s. 553-568.

Gillion F, Carpentieri L, "Construction Arbitration and BITs: Is There Still a Future for Intra-EU Investment Arbitration?”, 2018, Part 2, The International Construction Law Review, s. 167-181.

Hoppe T, "The German Federal Court of Justice Marks a Possible Way for the CJEU's Preliminary Ruling: The Compatibility of Investment Arbitration Clauses in Intra-EU Bilateral Investment Treaties with European Union Law”, 2016, 59, German Yearbook of International Law, s. 615-624. 
Karacan P, "Avrupa Birliğinde "Achmea” Kararı ve "1/17 Sayılı Görüş" Işı̆̆ında "Yatırımcı-Devlet" Uyuşmazlık Çözüm Mekanizmasının Geleceği”, 2020, 40(2), Public and Private International Law Bulletin, Prof. Dr. Cemal Şanlı'ya Armağan, s. 1507-1534.

Lenz C, "The Role and Mechanism of the Preliminary Ruling Procedure", 1994, 18(2), Fordham International Law Journal, s. 388-409.

Observations Provided by the Commission to Other Courts, <https:// ec.europa.eu/competition-policy/state-aid/national-courts/observationsother-courts_en> Erişim Tarihi 15.11.2021.

Opinion 1/17 of the Court (Full Court) Opinion pursuant to Article 218(11) TFEU, ECLI:EU:C:2019:341, 30 April 2019.

Opinion 2/13 of the Court (Full Court) Opinion pursuant to Article 218(11) TFEU, EU:C:2014:2454, 18 December 2014.

Opinion of Advocate General Wathelet, Case C-284/16, Slowakische Republik v Achmea BV, ECLI:EU:C:2017:699, 19 September 2017.

Regulation (EU, Euratom) 2016/1192 of the European Parliament and of the Council of 6 July 2016 on the transfer to the General Court of jurisdiction at first instance in disputes between the European Union and its servants, OJ L 200, 26.7.2016.

Sirmen K S, "The Concept of Public Policy in the Eco Swiss Decision of the Court of Justice of the European Union and Its Impact on the IntraEU Investment Treaty Arbitrations", 2021, 12(2), Inonu University Law Review, s. 438-449.

UNCITRAL, Rules on Transparency in Treaty-based Investor-State Arbitration, United Nations New York, 2014.

UNCTAD, Investor-State Dispute Settlement Cases Pass the 1,000 Mark: Cases and Outcomes in 2019, IIA Issues Note, Issue 2, July 2020.

UNCTAD, Investor-State Dispute Settlement Cases: Facts and Figures 2020, IIA Issue Note, Issue 4, September 2021.

UNCTAD, Investor-State Dispute Settlement: Review of Developments in 2016, IIA Issues Note, Issue 1, May 2017.

UNCTAD, Investor-State Dispute Settlement: Review of Developments in 
Abad'ın Achmea Kararı ve Yatırımcı-Devlet Uyuşmazlık Çözümü Açisindan...

2017, IIA Issues Note, Issue 2, June 2018.

UNCTAD, Investor-State Dispute Settlement: Review of Developments in 2018, IIA Issues Note, Issue 2, May 2019.

United Nations Commission on International Trade Law, Submission from the European Union and its Member States, Working Group III (InvestorState Dispute Settlement Reform) Thirty-seventh Session New York, 1-5 April 2019, A/CN.9/WG.III/WP.159/Add.1, 24 January 2019.

United Nations, Report of the United Nations Commission on International Trade Law, Fiftieth Session (3-21 July 2017), General Assembly Official Records Seventy-second Session, Supplement No. 17, A/72/17, New York, 2017.

Yusuf G, Tan G, Case Comment United Utilities (Tallinn) BV v Estonia, "ICSID Arbitration after Achmea: the Beginning of the End or the End of the Beginning?", 2020, 35(1-2), ICSID Review - Foreign Investment Law Journal, s. 1-14.

\section{KARARLAR}

Achmea B.V. (formerly known as Eureko B.V.) v. The Slovak Republic, Final Award, PCA Case No. 2008-13, 7 December 2012.

Charanne B.V. and Construction Investments S.à.r.l. v .Kingdom of Spain, SCC Case No 062/2012.

Electrabel S.A. v. Hungary, ICSID Case No ARB/07/19.

Eureko B.V. v. The Slovak Republic, Award on Jurisdiction, Arbitrability and Suspension, PCA Case No. 2008-13, 26 October 2010.

Ioan Micula and Others v. Romania, ICSID Case No ARB/05/20.

Judgment of the Court (First Chamber), Case C-168/05, Elisa María Mostaza Claro v. Centro Móvil Milenium SL, ECLI:EU:C:2006:675, 26 October 2006.

Judgment of the Court (First Chamber), Case C-567/14, Genentech Inc. v. Hoechst $\mathrm{GmbH}$ and Sanofi-Aventis Deutschland $\mathrm{GmbH}$, ECLI:EU:C:2016:526, 7 July 2016. 
Judgment of the Court (Fourth Chamber), Case C-125/04, Guy Denuit and Betty Cordenier v. Transorient - Mosaïque Voyages et Culture SA, ECLI:EU:C:2005:69, 27 January 2005.

Judgment of the Court (Grand Chamber), Case C-182/15, Aleksei Petruhhin, ECLI:EU:C:2016:630, 6 September 2016.

Judgment of the Court (Grand Chamber), Case C-196/09, Paul Miles and Others v. Écoles Européennes (European Schools), ECLI:EU:C:2011:388, 14 June 2011.

Judgment of the Court (Grand Chamber), Case C-284/16, Slowakische Republik (Slovak Republic) v. Achmea BV, ECLI:EU:C:2018:158, 6 March 2018.

Judgment of the Court (Grand Chamber), Case C-459/03, Commission of the European Communities v. Ireland, ECLI:EU:C:2006:345, 30 May 2006.

Judgment of the Court (Grand Chamber), Case C-741/19, Republic of Moldova v. Komstroy LLC (successor in law to the company Energoalians), ECLI:EU:C:2021:655, 2 September 2021.

Judgment of the Court (Second Chamber), Case C-377/13, Ascendi Beiras Litoral e Alta, Auto Estradas das Beiras Litoral e Alta SA v. Autoridade Tributaria e Aduneira, ECLI:EU:C:2014:1754, 12 June 2014.

Judgment of the Court, Case 109/88, Handels- og Kontorfunktionærernes Forbund i Danmark (Union of Commercial and Clerical Employees, Denmark) v. Dansk Arbejdsgiverforening (Danish Employers' Association), acting on behalf of Danfoss A/S, ECLI:EU:C:1989:383, 17 October 1989.

Judgment of the Court, Case 186/87, Ian William Cowan v. Le Trésor public (Treasury), ECLI:EU:C:1989:47, 2 February 1989.

Judgment of the Court, Case C-102/81, Nordsee Deutsche Hochseefischerei $\mathrm{GmbH}$ v. Reederei Mond Hochseefischerei Nordstern AG \& Co. KG and Reederei Friedrich Busse Hochseefischerei Nordstern AG \& Co. KG., ECLI:EU:C:1982:107, 23 March 1982.

Judgment of the Court, Case C-126/97, Eco Swiss China Time Ltd v. Benetton International NV, ECLI:EU:C:1999:269, 1 June 1999. 
Abad'ın Achmea Kararı ve Yatırımcı-Devlet Uyuşmazlık Çözümü Açisindan...

Judgment of the Court, Case C-337/95, Parfums Christian Dior SA and Parfums Christian Dior BV v. Evora BV, ECLI:EU:C:1997:517, 4 November 1997.

Judgment of the Court, Case C-393/92, Gemeente (Municipality of) Almelo and others v. Energiebedrijf Ijsselmij NV, ECLI: EU:C:1994:171, 27 April 1994.

Judgment of the Supreme Court of the United Kingdom [2020] UKSC 5 - 19 Feb 2020.

Magyar Farming Company Ltd, Kintyre Kft and Inicia Zrt v. Hungary, ICSID Case No. ARB/17/27.

Marfin Investment Group Holdings S.A., Alexandros Bakatselos and others v. Güney Kıbrıs Rum Yönetimi, ICSID Case No ARB/13/27.

Memorandum Opinion and Judgment of the United States District Court for the District of Columbia - 8 Nov 2021.

Memorandum Opinion and Order of the United States District Court for the District of Columbia - 20 Nov 2020.

Micula, Viorel Micula and others v. Romania (I), ICSID Case No. ARB/05/20.

Order of the Court (Eighth Chamber), Case C-555/13, Merck Canada Inc. v. Accord Healthcare Ltd, Alter SA, Labochem Ltd, Synthon BV, Ranbaxy Portugal - Comercio e Desenvolvimento de Produtos Farmaceuticos, Unipessoal Lda, ECLI:EU:C:2014:92, 13 February 2014.

RREEF Infrastructure (G.P.) Limited and RREEF Pan-European Infrastructure Two Lux S.à.r.l. v. Kingdom of Spain, ICSID Case No ARB/13/30.

Theodoros Adamakopoulos and others v. Güney Kıbrıs Rum Yönetimi, ICSID Case No ARB/15/49. 